\title{
主題（II） 長期透析における問題点
}

$$
\begin{array}{r}
\text { 司会平沢由平 } \\
\text { 千 野 一 郎 }
\end{array}
$$

演題 12 骨変化について

信楽園病院 鈴木 正司, 平沢 由平

演題 13 透析症例における骨組織的異常と副甲状腺摘除術の效果

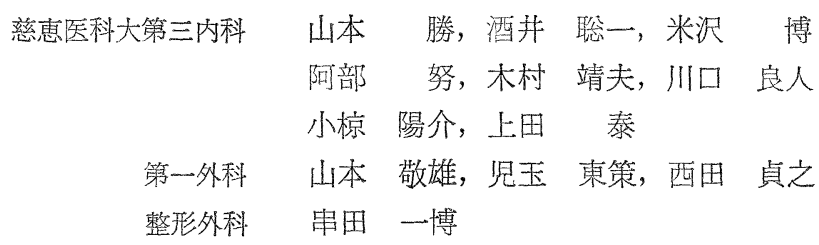

演題 14 長期血液透析患者における骨代謝異常の治療

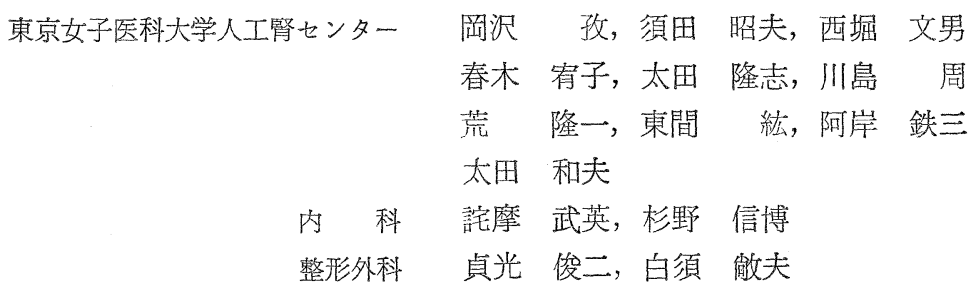

演題 15 Renal osteodystrophy のレ線学的ならびに病理組織学的検索

（特に定量的見地加引）

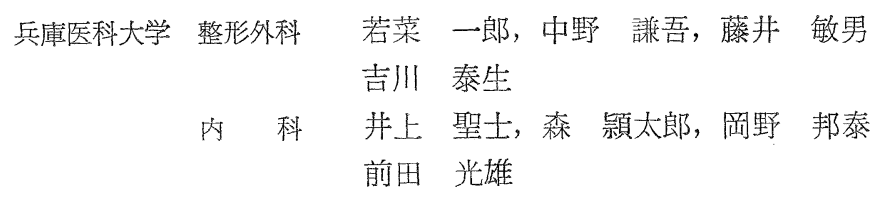

演題 16 慢性腎不全に招ける二次性副甲状腺機能元進症の研究

一一特に血清PTH濃度と骨変化との関係—

$\begin{array}{rlrl}\text { 北里大学 内r科 } & \text { 浅野 } & \text { 泰, 丸茂 文昭, 三科 孝夫 } \\ & \text { 木川田隆一 } \\ \text { 放射線科 } & \text { 松林 } & \text { 隆 } \\ \text { 泌尿器科 } & \text { 酒井 } & \text { 紏 } \\ \text { 外 科 } & \text { 内田 久則 } \\ \text { 整形外科 } & \text { 有富 } & \text { 寛 } \\ \text { 北里ブリストル } & \text { 佐藤 } & \text { 誠也 }\end{array}$

演題 17 慢性腎不全患者の骨変化について(第 1 報)腸骨生検の非脱灰標本観察とPTHについて

国立仙台病院 整形外科鳥越 絠二

東北大学 整形外科佐藤 光三, 森繁

仙台社会保険病院腎センター 関野宏, 石崎允, 高橋寿

閒間 弘道 
誌上発表 27 血液透析中の腎不全患者に見出された上皮小体腺腫の 1 手術例

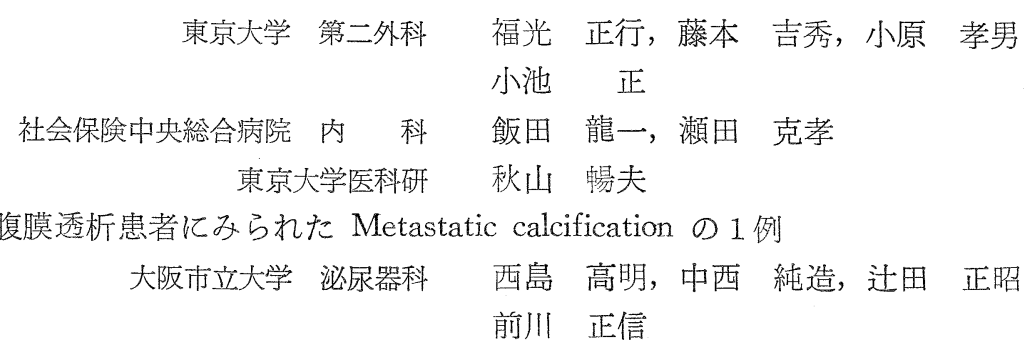

討論 


\section{(主題 II)}

\section{長期透析における問題点}

骨変化司会 平 沢 由 平
千 野 - 郎

千野 それでは，午後の部を始めたいと思います。

先ほど小高幹事から報告がありましたように，透析患 者さんが年々増加する，またそれに伴っての生存率も徐 々にであるが向上しているということは，非常に喜ばし いととだと思います。その生存率の向上に伴って，どこ でも経験するととだと思いますが，このIIのテーマにあ ります長期透析における問題点ということが種々取り上 げられるわけででざいます。昨年，北海道のときに, $\mathrm{Ca}$ 代謝という面から一応骨変化も含めて討論むありました が，本日は骨変化という面から見た問題というととで討 議していただきたいと思います。

それでは，演題12に，骨変化について，信楽園病院の 鈴木先生お願いいたします。

鈴木 私どもはとれまでの 10 年間に 363 名の慢性腎不 全患者の長期血液透析療法を施行してまいりました。乙 れらの患者の原疾患は, 慢性腎炎 233 名, 慢性腎孟腎炎 33名, 腎硬化症26名, 悪性高血圧症16名, 糖尿病性腎症 15名, 囊胞腎12名, S LE腎症 6 名, 痛風腎 6 名等が主 要なあのででざいました.

これらの患者の平均透析期間は 25.6 力でありまし て，年齢は20歳～50歳代に集中しております。透析療法 を開始した時点での最年少は 10 歳, 最年長は 74 歳であり ました. 現在最む長い透析歴を持つ患者さんは，9年を 超えております。

使用しました透析器も, ツインコイル，スタンダード キールから始まりまして, 現在ではコイル型, 平板型,

キャピラリー型の各種を使用しておりまして，更には吸 着剂を使用する方法も一部に取り入れております。透析 液作成用には，軟水化装置を通しました水道水を用いて おりましたが，最近では逆浸透法す導入しております。

いずれの場合にも，透析液中には弗素は検出されており ません，透析液酶酸度は $35 \sim 37 \mathrm{mEq} / 1$ ，透析液の $\mathrm{Mg}$ は $1.5 \mathrm{mEq} / 1$ ありました. また, 透析液の $\mathrm{Ca}$ 濃度む, 従 度までは $6 \mathrm{mg} / \mathrm{dl}$ を使用してまいりましたが， 72 年 4 月以降は $7 \sim 8 \mathrm{mg} / \mathrm{dl}$ の液を使用して㧍ります. 透析頻 手屯，従来までの週 2 回透析加ら，71年から72年にかけ まして週 3 回透析へ移行して扮ります．乙のような高 Ca液と頻回透析の導入によりまして,多くの例では低Ca
血症を見ることが少なくなってきております.

図1はてれまでの363名の患者に見られましたCa 代謝 異常所見の出現頻度を示したものであります．とこでは 骨の脱灰質変化については取り上げてでざいませんが, 血管壁石灰化，骨膜下吸収，軟部組織の石灰化，病的骨 折等が透析期間の延長に伴って增加して扣ります。骨折 例は 15 名で, 助骨 9 名, 大腿骨 3 名, 側骨 2 名, 尺骨 1 名ででざいました。助骨骨折の 4 名は再発性あるいは多 発性ででざいました。

昨年12月末，長期透析を継続中の 200 名の患者を対象 にしまして, 手指骨, 腰椎, 股関節部を含む骨盤のレ線 学的な検討を行なった結果を順次お示しいたします。

まず最初の手指骨は，200 名全例で検討いたしました が，異所性石灰化は $2 \% ，$ 血管壁石灰化は $5.5 \%$ に認め られました。また，指骨での骨膜下吸収像の判定には，

図 1

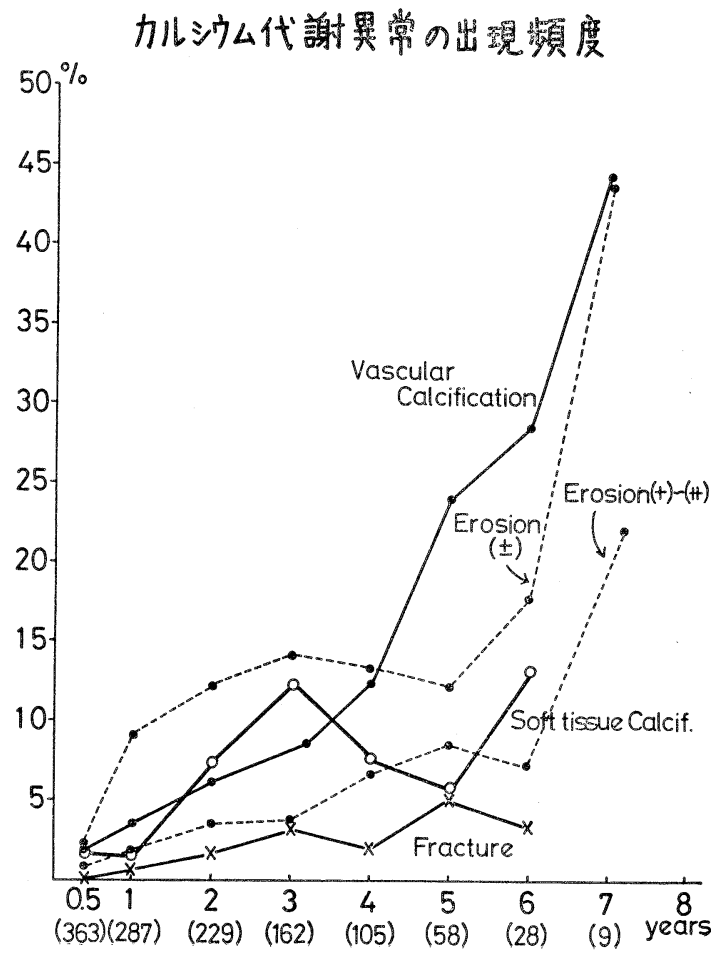


表1 骂

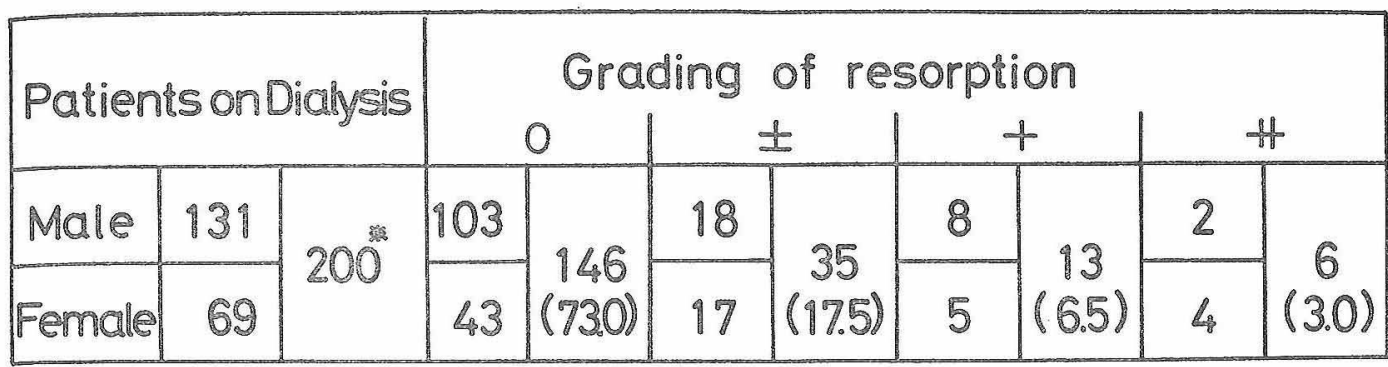

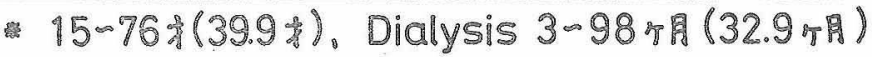

\begin{tabular}{|l|c|c|c|c|c|}
\hline Meema H.E.etal & 3. & 0 & $t$ & H & H \\
\cline { 2 - 5 } Radiol.102:1.972 & 38 & $19(50.0)$ & $8(21.5)$ & $7(18.4)$ & $4(10.5)$ \\
\hline
\end{tabular}

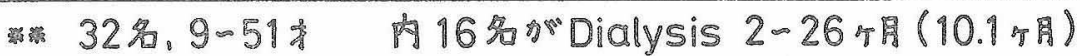

图 2

これまでの肉眼的読影法をやめまして，2 倍の拡大鏡下 でもって Meema 拡大撮影法てよる判定基準をやや改变 したものを用いて行ないました。

これは中手骨の外縁部骨膜が平滑なものをゼロ，やや 平滑さを欠くすのは土，虫食い状の所㫕で笳娄縮 $1 / 2$ を 超えないものでナ，それ以上のもの立州と判定いたしま के.

焉 【に200例の判定結果をまटめたものを沶ししま したが, +と判定したものは13例, 卉判定したすのが 6 例, 合計19例が副甲状腺機能進症亡考えられました。 とれは対象患者の $9.5 \%$ 亿相当し，注目されます。ま た，下の闌に示しましたのは Meema のむのでござい ますが，愁どあの十〜代対応するのとしてH〜州の 例が28.9\%どぜいます。彼らは私よ゙もよりも更に高い值 を報告しております。

骨軟化吸收が陽性を示した例と陰性の群と比較してみ ますと(图 2)，統計的には，陽性群で血清 $\mathrm{Ca}$ 值がやや 高く、アルカリ・フォスファターゼ值はかなりの高值を

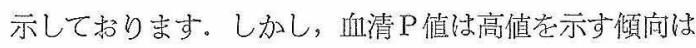
ございませんでした。

アルカリ・フォスファターゼのアイソザイムの泳動像 でみますと18，19は朋疾恕患者の血清でアルカリ・フォ スファターゼ 2 と考えられます. 20 な骨膜下吸収像井之 判定した患者で, アルカリ。フォスファターゼが40単位 の症例の血清でございますが，2及び 4 の中聞の位置に

\section{骨膜下吸收像と血湤尘化掌}

$N=35$

8 $-40$

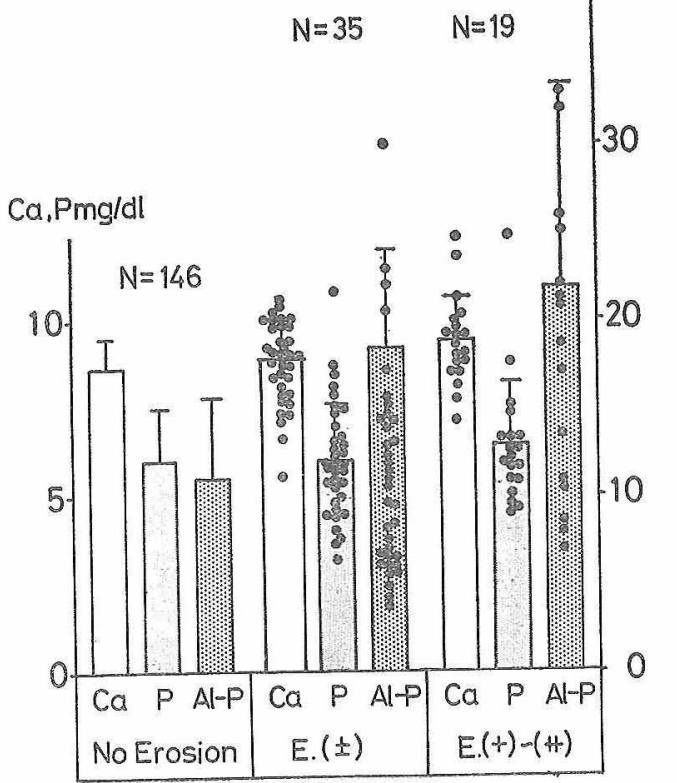


図3

\section{中手骨指数の变化}

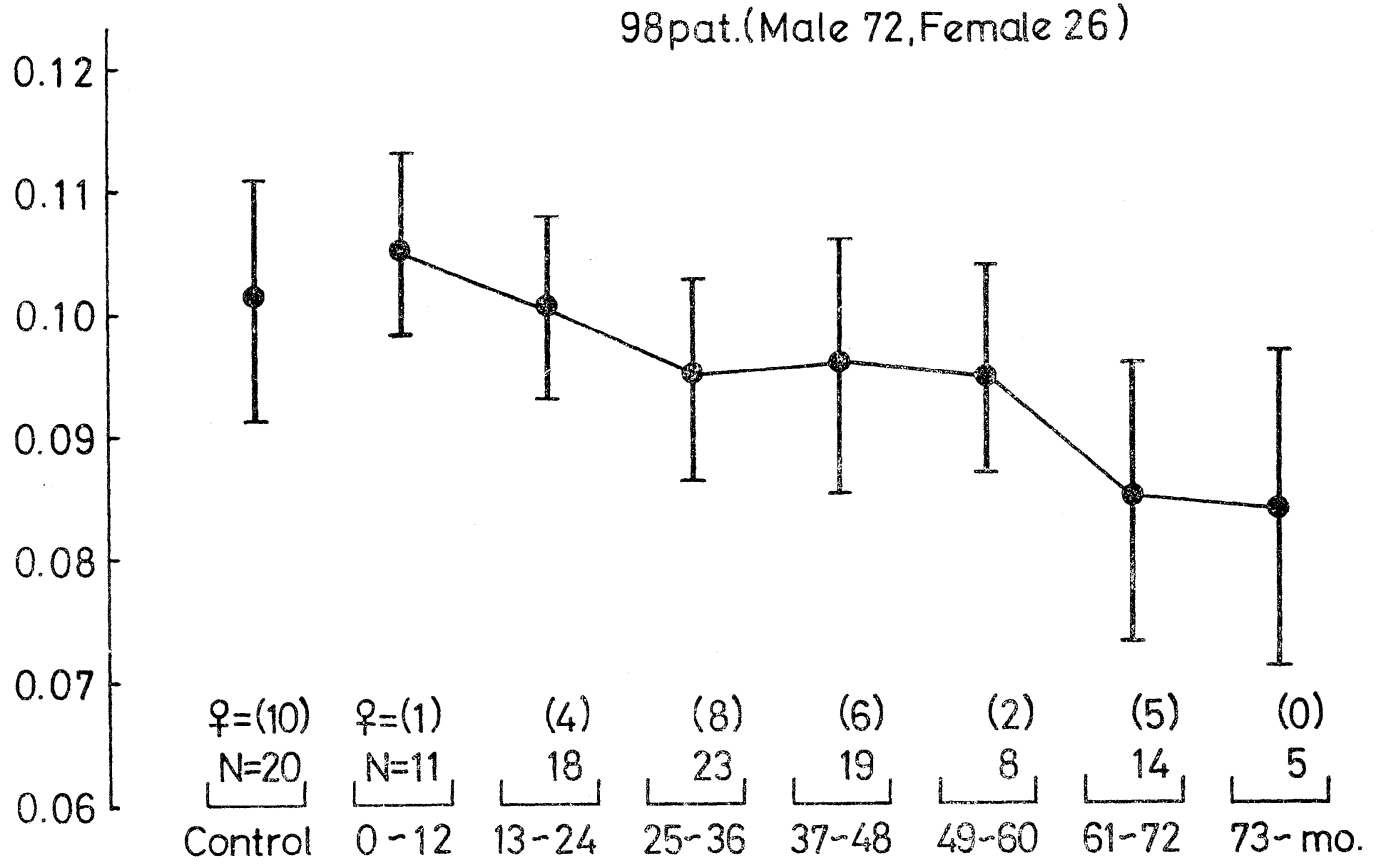

泳動されて拈りまして,アルカリ・フォスファターゼ 3 ,

図 5 はその結果を和示したものでございますが，中手 すなわち骨由来のアルカリ。フォスファターゼと考えら れました．とのように，骨膜下吸収が陽性の例では骨破 壞を裏付ける骨由来のアルカリ・フォスファターゼが増 加する場合が多いわけですが，アルカリ・フォスファタ 一ゼ值が正常域を示している例も見逃せません。

図 3 は先ほどの 200 例中で，加齡による影響の少ない 20歳〜40歳の98例につきまして，中手骨指数を算出して みたすのでございます。男文差を無視して表示してでざ いますが，透析期間の延長に伴いまして指数が低下し， 脱灰が進行する傾向がわかります。

腰椎の二方行撮影を行ないましたものは 158 例でござ いますが，圧迫骨折を10例，6.3\%に認めております。 また, 胸椎様変形，あるいはくさび状の変形を 37 例, 23.4\%と高率に認めております.

椎体上下縁の硬化像を示したものでございますが，乙 のような例が 3 例認められました。

次に，手指骨の場合亡同様に20歳４0歳の患者72名に つきまして, 痛みの骨粗鬆症の分類を当てはめてまみし た.との方法は，椎体の横と縦の骨稜の減少程度によっ て土から 3 度に分類するすのででざいますが，図44そ れを図式化したすのでございます。 骨指数之同様化，腰椎骨での骨粗鬆症は透析期間の延長 に伴って進行する傾向がわかります。

股関節部を含む骨盤のレ線撮影を行なった 159 例につ いての結果では，大腿骨頸部での骨折が 1 例, 離骨折, つまりルーサースゾーンを 1 例認めました。 そして，大 腿骨骨折例では囊腫様变化を半なって招りました。大腿 骨のシャフトの一番下部のととろに見られる所見です.

図ó は大腿骨骨頭部の骨稜の消失状態汃ら骨粗鬆症の 程度を判定する Singh の分類老模式化したものでござ います．乙の分類を用いまして，20歳４0歳の73名につ いて検討してみました。

図7はその結果を図示したあのでございますが，透析 期間の延長に伴いまして骨の脱灭が進行してくる傾向 は，前に示しました中手骨指数と，腰椎の痛みの分類の 場合と同様でございます。

表 2 はこれまでに判明いたしました骨の組織学的検討 の結果を示したものですが, 剖㭘例 9 肋骨は13例, 生検例 の腸骨 9 例，計22例を沶しいたしました．表では，透 析期間及び組織学的飞判定した骨粗鬆症 OP と記してあ りますが，乙れから，骨軟化症OM，線維性骨炎 OF の 程度を示してらります。骨折しました肋骨の横截切片で 

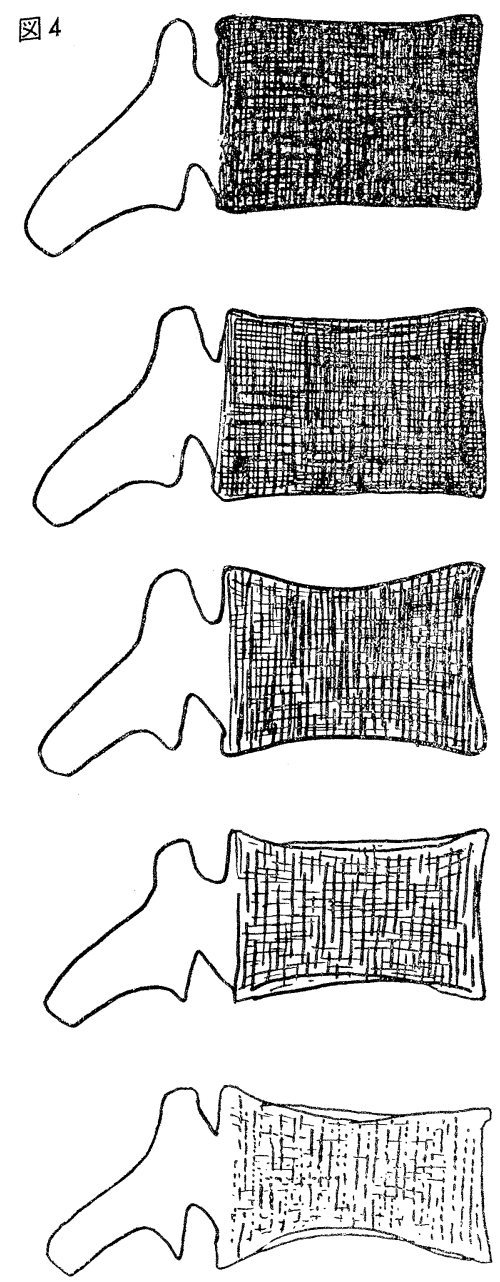

3

$\pm$

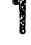

2

\section{Normal}

琑椎骨の脱灰

72 pat. 552, 우20 aver. 30.2 y. H.D. $6 \sim 98 \mathrm{mo}(42.7 \mathrm{mo}$.)

\begin{tabular}{|c|c|c|c|c|c|}
\hline Grade & 3 & 2 & 1 & \pm & Nomal \\
\hline \multicolumn{6}{|c|}{ H.D. (mo) } \\
\hline $0-12$ & & & 0 & & $\infty$ \\
\hline $13-24$ & & $\infty$ & $\infty 000$ & 9888 & \\
\hline $25-36$ & & & 98380 & 0000 & 0 \\
\hline $37-48$ & & $\infty \infty$ & 888880 & 000 & \\
\hline $49-60$ & & 0 & 8880 & 0 & \\
\hline $61-72$ & 0 & $\circ$ & 98080 & $\circ$ & \\
\hline $73-84$ & & 0 & 0 & 0 & \\
\hline $85-$ & & & $\infty$ & & \\
\hline
\end{tabular}

図7

\section{大腿骨頭の脱兏}

73 pat. 553 . 820 aver. 30.2 y. H.D. $6 \sim 98 \mathrm{mo} .(42.5$ mo.)

図 6

$$
\text { etal.1966) }
$$
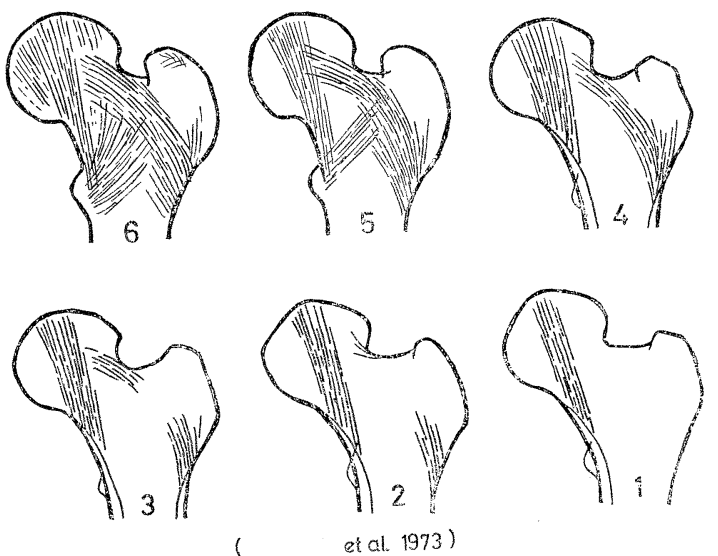

$49-60$

$61-72$

1

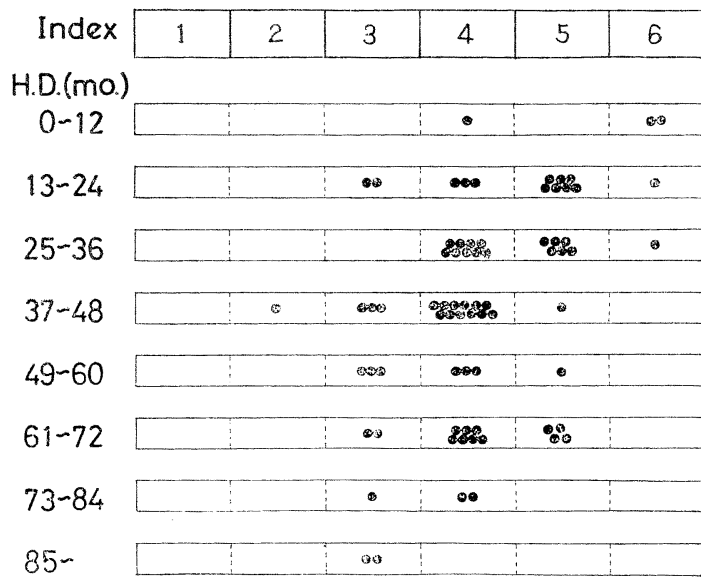


表 2

\section{遥析患者の骨組織像}

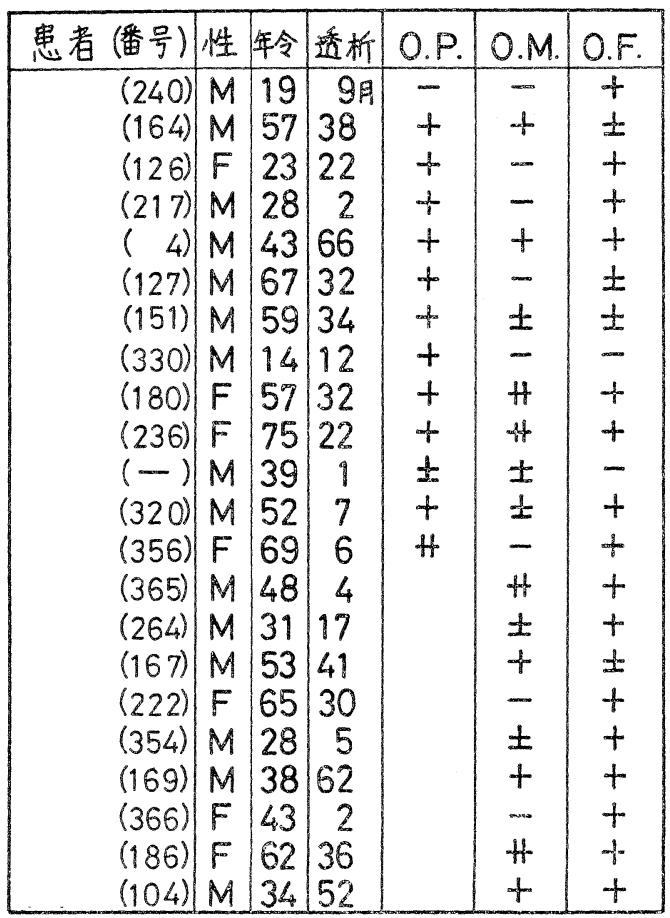

非脱灰標本を作成しまして，全断面積住対する骨皮質の 比, $\mathrm{C} / \mathrm{T}$ 比を求めて, 骨密度の指標としてみますと, 13例中11例までが骨密度の低下，すなわち骨粗鬆症を呈 し，C/T比は透析期間の長いほざ低下する傾向がござい ますが，必ずしもそれに当てはまらない場合むございま した，肋骨，腸骨の非脱灭標本にテトラクローム染色を 行ない，骨内膜面での吸収化面，形成化面，休止化面の 割合を求めてみますと，吸収化面，形成化面の增加して いる例が多くありました。また, 単位面積当たりの類骨 層を伴う二次骨床単位之吸収腔数之の比, $\mathrm{AR} / \mathrm{AF}$ 比加 ら骨の再棈筑バランスを求めてみます之, 吸収腔数の多 い症例が目立つ反面で，逆に，類骨層が多く，幅む広く なっていて，骨軟化症と考光られる例も少なからず見引 れました。

また，副甲状腺ホルモンが骨細胞に直接的に作用して 骨吸収を引き起てしていると言わ机ます骨小腔域の増加 の見られる例も多く見られました。

以上をまとめてみますと，骨粗鬆症，骨軟化症，線維 性骨炎等の骨変化は，個々の患者にそれぞれ全く無関係

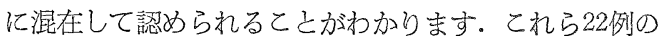
場合には，骨粗鬆症は約 $85 \%$ ，骨軟化症将約 $41 \%$ ，そし
表 3

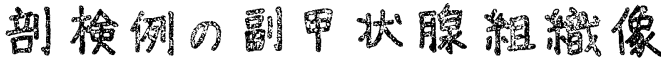

\begin{tabular}{|c|c|c|c|c|c|}
\hline & 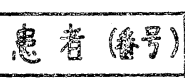 & 性 & 安令 & 遥新 & 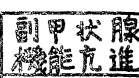 \\
\hline 1 & ( 23$)$ & $M$ & $32 \pi$ & 30 : & + \\
\hline 2 & (4) & $M$ & 43 & 66 & \pm \\
\hline 3 & (135) & $F$ & $44_{3}$ & 10 & - \\
\hline 4 & $(24,0)$ & $M$ & 19 & 9 & + \\
\hline 5 & (217) & $M$ & 28 & 2 & - \\
\hline 6 & $(194)$ & $F$ & 47 & 26 & - \\
\hline 7 & (151) & $M$ & 59 & 34 & + \\
\hline 8 & (330) & $M$ & 104 & 12 & + \\
\hline 9 & $(180)$ & P & 60 & 32 & + \\
\hline 10 & $(-)$ & $M$ & 39 & 1 & $t$ \\
\hline 11 & (320) & $M$ & 52 & 7 & $t$ \\
\hline 12 & (356) & $F$ & 63 & 5 & + \\
\hline 13 & & & & & \\
\hline 14 & & & & & \\
\hline 15 & & & & & \\
\hline
\end{tabular}

て線維性骨炎付約73\%に認められました。骨組織像から 骨軟化症と診断された9例で，レ線的にルーサースゾー ン它認めた症例はございませんでした，また，線維性骨 焱々誩断された16列で，レ線的に私どもの判定基準に合 わせて骨膜下吸収像が陽性である之認好た症例は 1 例に

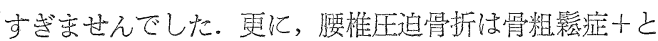
H判定した群の3例にのみ見られました。

この例では，緑色汇染まって和ります類骨層が，石灰 化起受计ずに骨内膜面偪应く存在しておりまして，ビ タミンD无による骨軟化症が主体之診断されます。

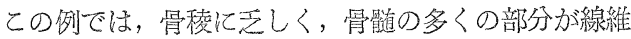
性組織で覆われておりまして，副甲状腺ホルモンの過剩 によります線維性骨炎子彰断された例ででざいます。

次に，乙れまでの剖検例から得られました副甲状腺を 検討してみますと（寅了），著明な肥大を見た例では， $1.2 \mathrm{~g}$ の重量を持つ1例だけででざいまして，そのほか は正常古るいはやや肥大していると判断さ礼る程度の屯 のででざいました。表に示すでとく，元の組織像から は，副甲状腺機能六進症之彰断された例は，疑わしい例 
あ含めまして75\%にあなることがわかりますとていの 陽性例で，アルカリ・フォスファターゼが高值を示す場 合とそうでない場合とがありました。また，副甲状腺組 織像と骨組織像との関連性を 9 例について検討してみま したとてろ, 機能立進症として両者の診断が一致したの は 9 例中 6 例でございました。

正常な機能状態と考えられる副甲状腺組織像では全体 的に濃く染色された細胞が棚状の配列をしておりまし て，脂肪退縮屯各所存在しております.

この例では，構成細胞が明るい主細胞で占められてお りまして，核の占める比率む低下しております，そし て, 棚状の配列を失いまして, 小葉状あるいは腺様構造 を呈しておりまして, 明らか机機能无進状態亡考えられ るあのででざいます。

以上, 私どあの 10 年間の長期透析療法の経験から, 骨 変化を主体に述へてみました。 レ線学的にも, 組織学的 にも骨変化は高頻度に認められ, 更に, レ線上では病的 変化として指摘し得ない例でも, 骨組織学的には既に骨 軟化症や線維性骨炎が高率に認められるという事実は, 見逃すととができません.また, 副甲状腺の組織 像で $2 / 3$ が機能元進状態を示した点も注目されます。

透析療法は目覚ましく普及して, 技術屯進歩し, 心不 全, 感染症, 脳血管障害, 高 $\mathrm{K}$ 血症などの合併症で死亡 する例は少なくなってまいりましたが，骨変化付対しま す私どあの取り組みはまだ完全ではありません，透析液 の処方, 透析の頻度, 活性型のビタミンD, 副甲状腺に ついて検討が更に必要と思われます。

終わりに，骨の組織学的検討の御指導をいただきまし た浜組学園則松先生に感謝の意を表します。

千野 続いて, 演題13, 透析症例に招ける骨組織的異 常之副甲状腺摘除術の効果, 慈恵医大の山本先生书願い いたします。

山本 本邦に扔いてす, 長期透析例か増加するにつ れ，骨病変が無視できないものとなってきていると考え

図 1

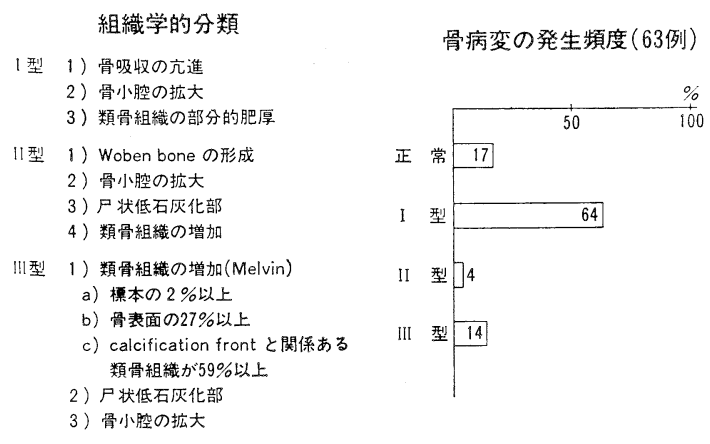

ます。そこで, 私たちは慢性腎不全63名の剖検ないし生 検による骨組織学的検索を進め, 図 1 のごとき成績を得 ました．乙れらの病変は I 型, II 型, III型にまとめら れ，I 型は副甲状腺機能九進による所見に相当し， III 型 はビタミン D作用の欠之を主因とする骨軟化症に相当し ます、II型は，I型之 III型の移行，あるいは混在した型 と考えられます。乙れらの変化の発生頻度を見ますと, 正常が17\%，I 型64\%，II 型 4\%，型14\%であり，83 \%の高率に何らかの骨病変が見られました. 特に I 型, すなわち二次性副甲状腺機能元進による病変が最も多く 見られます，それに対して，北欧とか英国に多いと言わ れている III型，すなわち骨軟化症の所見は，わずか $14 \%$ にすぎません・

透析療法之骨組織変化の関係を見ますと（図 2), 透 析開始前では，正常33\%，I 型40\%，II 型はなく， II 型

図 2

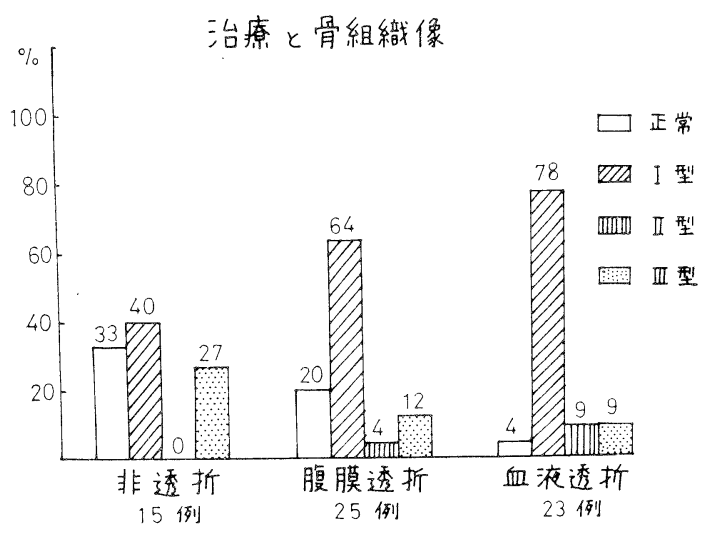

表 1

\section{二次性副甲状腺機能亢進症に対する治療法}

I ) 薬物癔法

1. Calcium凮 15 20g/day

2. ビタミンD大繁投与 $100,000 u$

3. 活性型ビタミンD D D D T

$\left\{\begin{array}{l}1,25-(\mathrm{OH})_{2}-\mathrm{D}_{3} \\ \mathrm{I}-\mathrm{OH}\end{array}\right.$

4. Calcitonin (?)

5. Diphosphonate

6. Aluminum hydroxide gel

II 高Calcium透新液

III]堅移植

IV)副甲状腺亞全摘術 
は27\%であります，それに対して，透析例老腹膜䢪析と 血液透析飞分壮てみますと，腹暁透析では I 型が64\%と 增加し，血液透析では1型が更に78\%と增加します。そ れに対し正常，吕型，巩型は少なくなります。このとと は，長期透析例の大多数に副甲状腺穴進に上る骨病変が 合併しているととを示しています，てのような成績は米 图执いて報告されている成績とよく一致して倣りま す.とれらの症例での骨組織学的所見とX線所見を刘比 してみますと，必ずしすX線に巽常を認好て打りませ ん.したがって，X線所見で暴常を認めなくとも既に骨 組織学的に異常办存在するととを示唆しています。

透析例认高率化合併する二次性副妇状腺機能元進症の 治寮法として，今日，表 1 のでとき檑々の方法が举げら 机ています。特に私たちが PTH 分泌元進の根源とあ考 える督障害によるビタミンDの活性化障害に対して，活 性型のビタミンDの開発が盛んに行なわれ, 更にPのコ ントロール，高 $\mathrm{Ca}$ 透析液使用によってPTH 過剩分泌 を排制する方法方洘元られ，二次性副甲状腺機能穴進症 による霄病衤が減少してきたと言われています。しか

図 3

$38 \mathrm{yr}(\mathrm{M})$
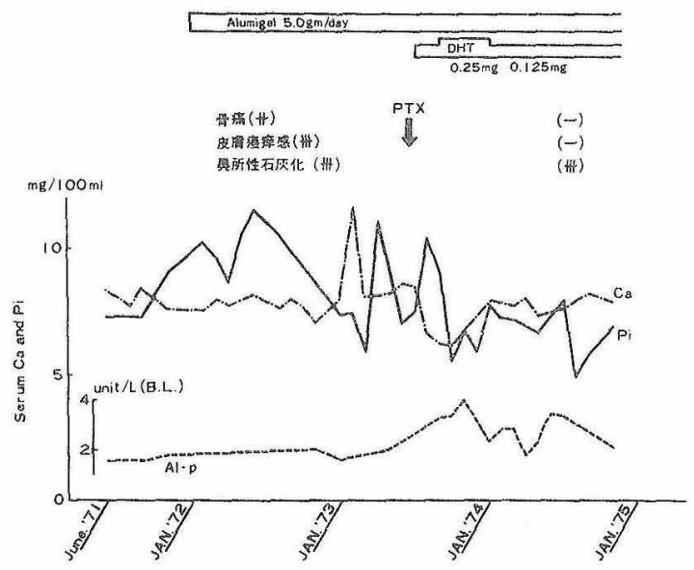

图4.

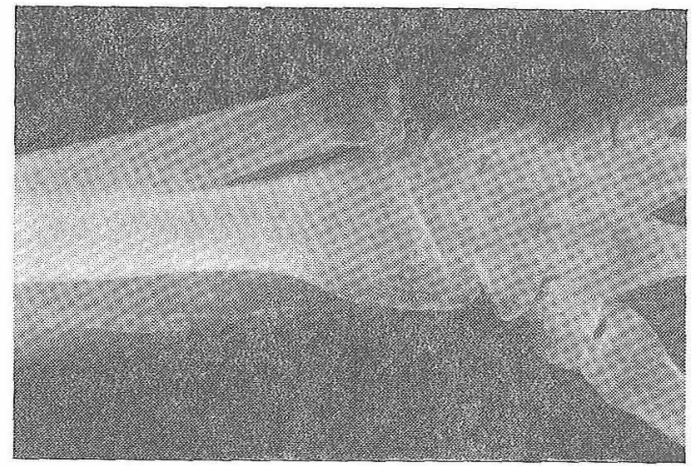

し，とれらの保存的な方法では，全例飞 PTH 過剩分泌 を扬制するととは期待できません。そとで，私たちは 5 例偪甲状腺摘除術を施行したので，その成績を報告 し，その効果，適応，合併症などについて幾つかの問題 点を述べてみたいと思います，

図 3 は38歳男性, 慢性系球体腎炎による緊不全で，4 年前から腹膜透析により管理をしておりましたが，透析 初期より高度の皮膚癌㾕感，骨痛立びに全身の血管石死

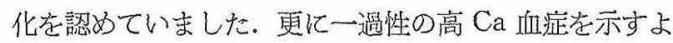
うになり，副甲状腺摘除術を施行しました，なお，本例 图 5

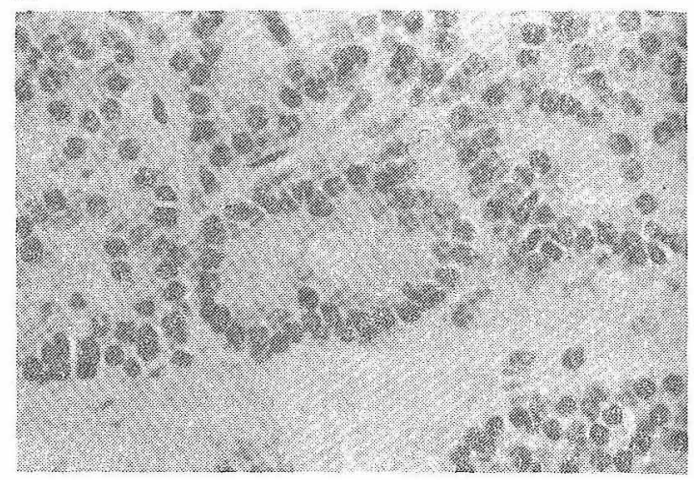

図6

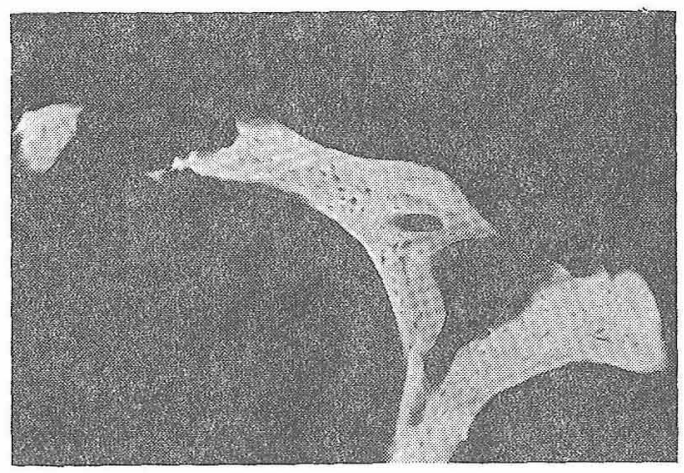

圈7

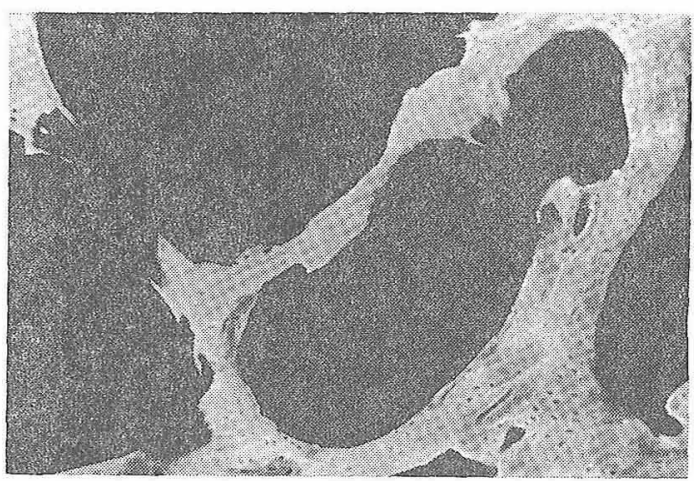


のCa 負荷試験で血中 iPTHは抑制されませんでした。 術後 3 日より血清 $\mathrm{Ca}$ 濃度は低下し，何度かテタニー発 作を認めましたが，DHT の増加によりテタニーは見ら れなくなり，皮膚瘦瘈感，带痛は消失し，血管の不灭化 あ改善傾问党認めました。

この患者の副甲状腺摘除前の前腕のX 線写真で（図 4)，橈骨動脈の著明な石灭化を認め，乙のため内シャ ントが作れず，現在㫗腹膜透析老行なっております。

図 5 は摘除した副甲状腺の組織で, 主細胞による過班 成と同時に腺腫様構造も形成している部分を認めます。

図6は副甲状腺摘除前の腸骨生祫によるコンタクトマ イクロラジオグラフで，骨吸収と骨小腔の拡大が認めら れ，乙れい二次性副甲状腺㙨能立進による骨病変の所見 と思われます。

図 7 は副甲状腺摘除 3 力月後の組織像ですが，骨組織 学的には改善は認められませんでした。

図 8 の症例は，41歳，女性の慢性腎不全で，原疾患は 図 8

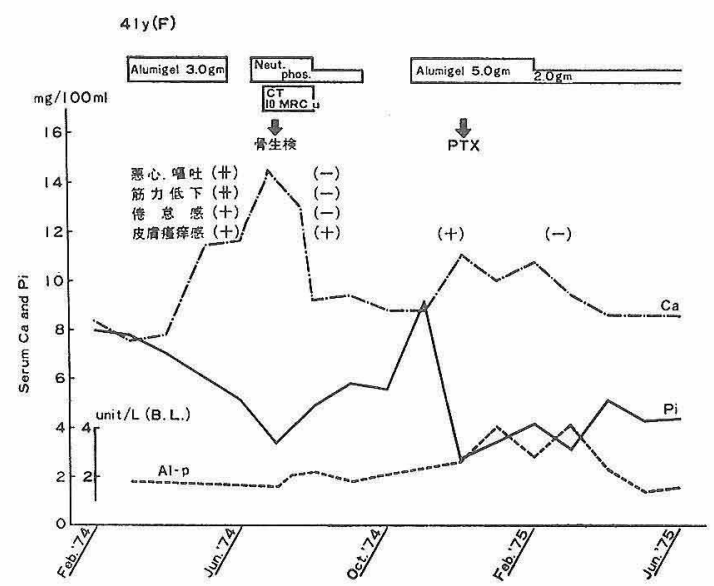

図 9

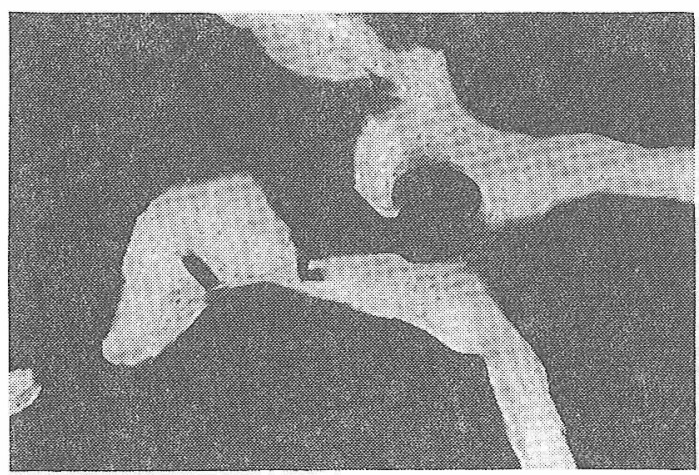

前同㥞，谩性糸球体呰炎です. 腹膜透析開始 4 力月後よ り血清 Ca 濃度が上界し, hypercalcemic crisiを米し, 恶心，嘔壮，筋打低下，僚怠感などを挀え，血清 $\mathrm{Ca}$ 濃 度は $14.6 \mathrm{mg} / \mathrm{dl}$ まで上昇しました。そてで neutral phosphate 並びにカルチトニンを投与し，腹膜透析液 の Ca 濃度を $4.5 \mathrm{mg} / \mathrm{dI}$ そ下げ，腹膜透析を行ない，高 Ca 血症は改篦しました。しかし，再び高 $\mathrm{Ca}$ 血症を認 めたため，副甲状腺摘除を施行した例です。

そのときの骨生検のコンタクトマイクロラジオグラフ による骨組織所見で（図9），比較的軽度ですけれども， 骨吸収と骨小腔の拡大が認められ，乙れも副卌状腺譏能 克進による骨病変と認められます。

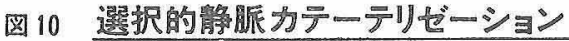

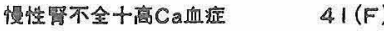 iPTH $\mathrm{ng} / \mathrm{ml}$}

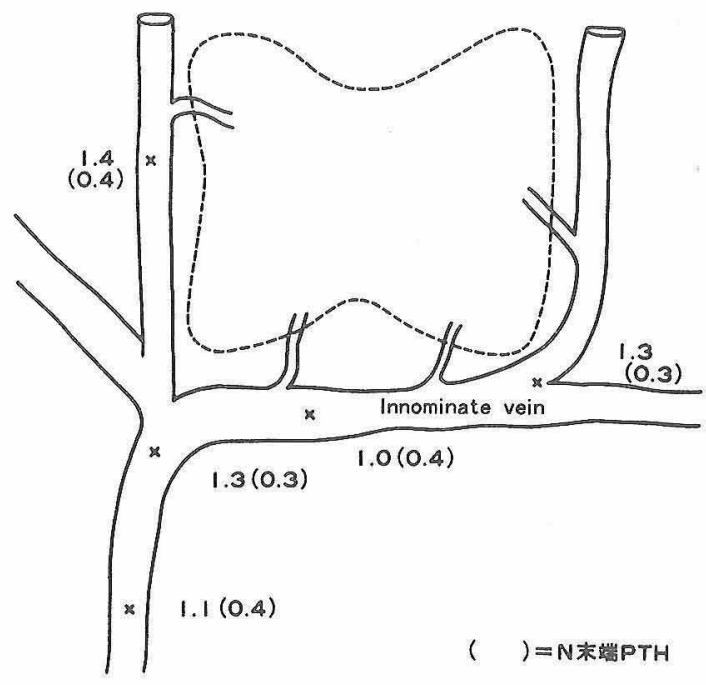

図11

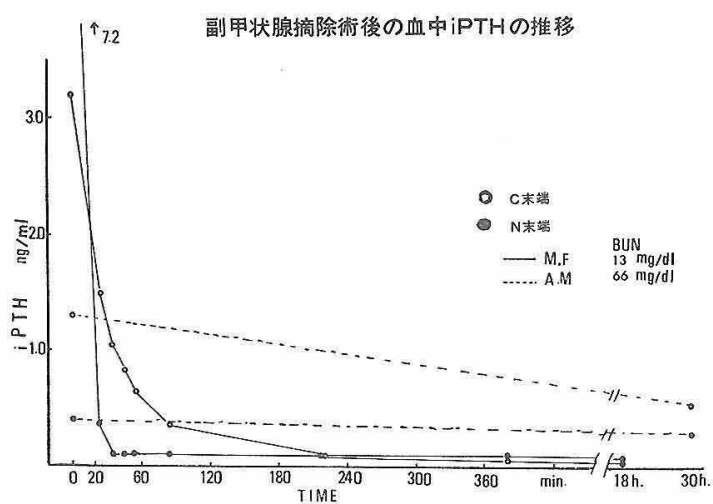


この症例では，一次性副甲状腺機能穴進症との鑑別跈 断のために，選択的静脈カテーテリゼーションを施行し （図10），血中 iPTH の局在性增加があるか否かを倹索 しましたが，いずれの部位であiPTH の增加が見られ， 局在性の増加は認められませんでした。なお，Ca 負荷 試験で，血中 $N$ 末端 $\mathrm{PTH}$ はやや低下しましたの で，過形成と䛦断しました，乙の症例でも，術後，皮膚 瘦㾕感は消失し，その後は高 Ca 血症を認めておりませ ん.な拉，摘除した副妇状腺組織は過形成でありました。

国11は一次性副甲状腺機能允進と本症の副甲状腺摘除 後の血中の iPTH 減衰曲線を比較したものですが，穾 線で示した一次性副甲状腺機能立進症では iPTH の半 減期は図のでとく短時間であるのに対し，慢性腎不全で は点線のでとくで，マズリーらの報告にああるごとく， 著明に延長しておりました。

図12には38歳, 男性で, 著名な第3 指のアンガータフ ト・エロージョンと第 2 指太節骨の骨膜下吸收像を示す レ線で, 高度の副甲状腺機能え進による変化を認めます が，図130ように副甲状腺摘除 3 カ月後には改善してい ます。

以上，副翈状腺摘除により骨病変が改善しなかった

\section{図12}

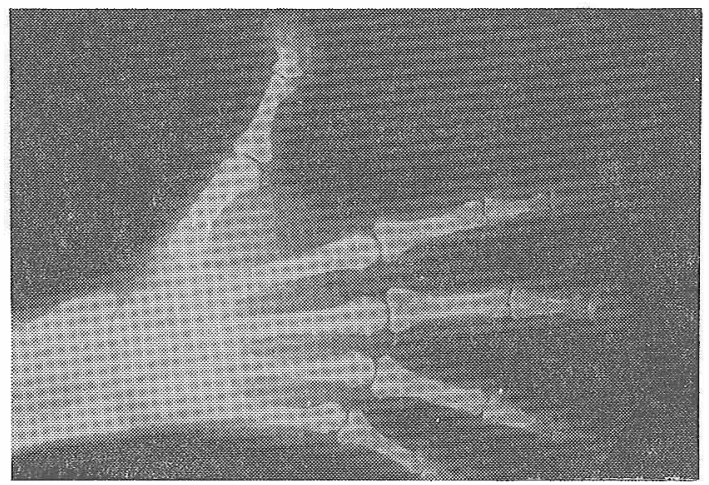

図13

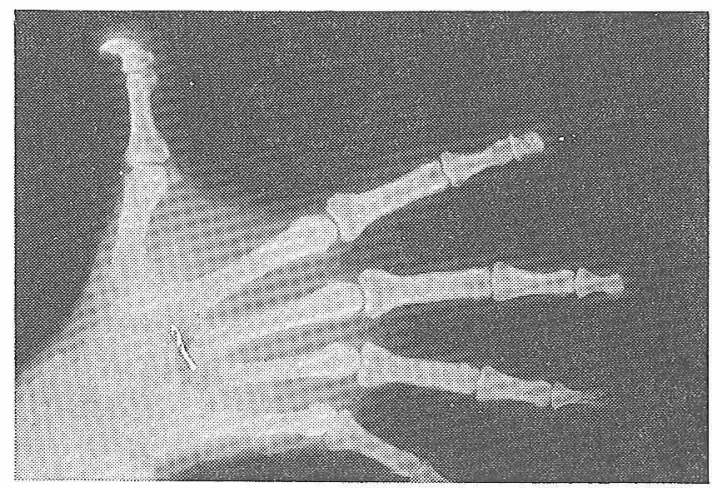

例，改善した例を示しましたが，副甲状腺摘除術を施行 した 5 例の術前・術後各 1 力月間平均 CaXP の積を比 較してみますと（図14），術前の5 例平均は83であるに 対し，術後は47亿低下しております，CaXP 積が60～70 を超す之新移性石灰化が增強する傾向にありますが，副 甲状腺揇除仗よってての危険を少なくすることができま

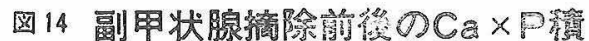
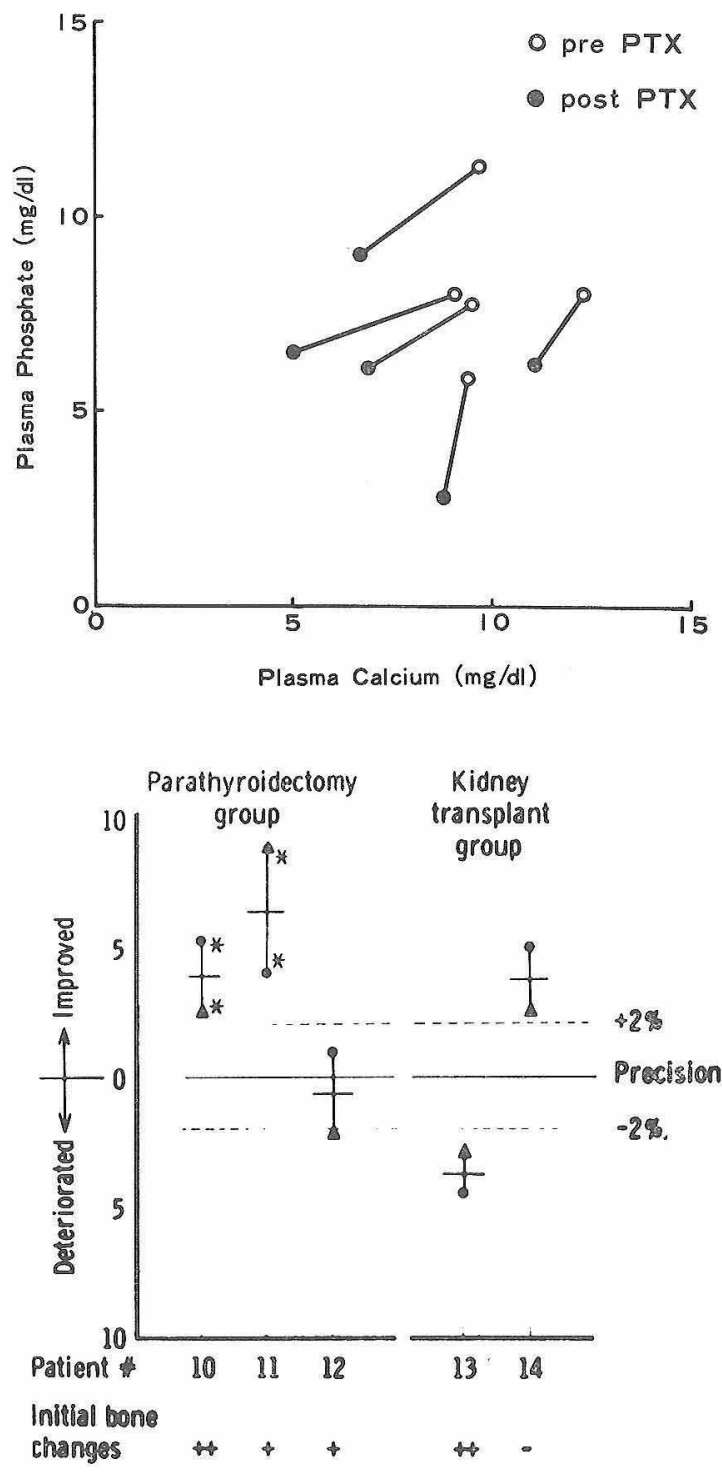

- Distal phalanx

$\triangle$ Middle phalanx

* With identifiable $x$-ray change

圆 15 
した，術後の CaXP 積が減少する因子は，PTH 分泌 現象のみならず，術後に投与したアルミニウム・ハイド ロオキサイドや，術後のため積極的に行なった透析によ る影響字ると思われます。

また，てれらの症例の一部について末節骨と中手骨の ボーン・ミネラル・アナライザーによるボーン・ミネラ ル・コンテンツの测定結果ですが (図15), 副甲状腺摘 除 3 力月後には, ボーン・ミネラルの增加したものが 3 例中 2 例ありました。

\section{表 2}

\section{副甲状腺覀全摘術後の合併症}

(1)テタニー,㾏晋発作

(2)骨折,

（3）精袖障害(情動不媱，抑うつ)

(4)暴所性石灰化の增強

（ビ夕ミンD投与，PO4のコントロール不良）

図16

TRANSITION OF BLOOD CHEMISTRIES BEFORE AND AFTER PARATHYROIDECTOMY Subtotal parathyroidectomy
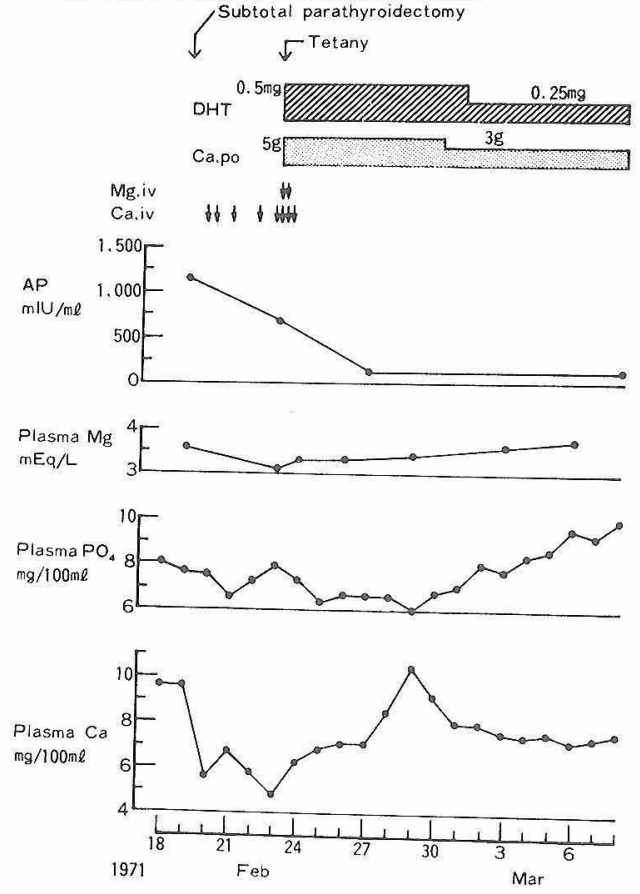

一方, 副甲状腺摘除術には種々の合併症も報告されて います、最も一般的なすのは，血清 $\mathrm{Ca}$ 濃度の低下によ

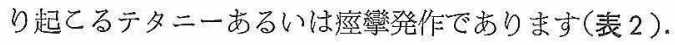
また，副甲状腺摘除捘，ビタミン $\mathrm{D} ， \mathrm{Ca}$ 剂を投与しま すが，その際，Pのコントロールが悪いとかえって転移 性石灰化を增強する結果となることもあり得ます。

図16の例は, 副甲状腺挏除後, 血清 $\mathrm{Ca}$ 濃度の低下之 共に血清 $\mathrm{Mg}$ 濃度す低下し，テタニー発作を起こし， 肩甲骨骨折を起ししました。乙の例では, テタニー発作 抑制に Ca 羭のみでは効果が得られず， $\mathrm{Mg}$ 剂の投与も 必要としました。図17は，いまの症例の肩甲骨骨折のX 線写真であります。

以上のごとく副甲状腺摘除には種々の効果があります が，果たして副甲状腺摘除術の適用はどうでありましょ う。今日のように保存的飞行なうメディカル・パラサイ ロイデクトミーが発達した時点では，てのような手術侵 襲を加えるととが必要であるか否かの論議が多いととろ であります。現在考えられる適応については, 表了のご とくになりますが,メディカル・パラサイロイデクトミ

図17

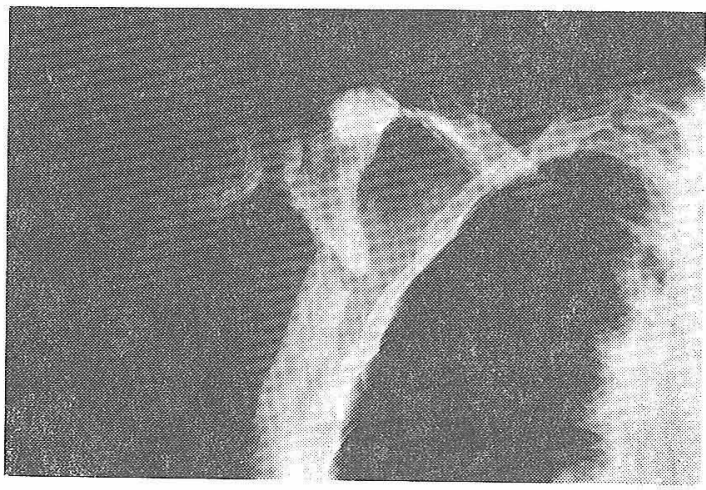

㤗 3

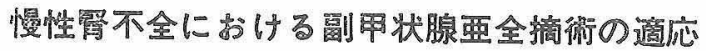

（1）非部制柱の副甲状腺機能元進 iPTH 高値, Ca 負荷に不応

（2）保存的療法に不応で以下の臨床症状 宗す症例

異所㤬石灰化

皮肩瘦㾕感

骨病変

(3)高Ca血症

(4) 腎移植前 
一を行なっても更に進行する骨病変, 転移性石㚒化の搪 大，あるいは持続する高 $\mathrm{Ca}$ 血症ないし移植を前提とし た場合は，まだ必要性を全く否定するわけにはいかない と考えています。そしして，Ca 負荷試験によって非卯制 性である場合には，副甲状腺摘除が適応となると思わ机 ます。

\section{以上より次のごとき結語を得ました。}

1。慢性腎不全では, 例え骨X線で異常を認めなくと 屯, 骨組織学的に $83 \%$ に異常を認め, 二次性副甲状腺機 能え進に上る骨病変が多い。

2. 副甲状腺摘除の適応として, Ca 負荷試験によっ て非抑制であることが参考となる。

3. 副甲状腺摘除により皮顱痊㾝感, 骨痛は消失, 転 移性石灰化は改善傾向を認好る。玑し bone densitometry, X線学的に改善か認められて屯, 骨病変が持続 する症例すある。

4. 副甲状腺摘除後, 低 $\mathrm{Ca}$ 血症注意しなけ扎ばな らず，ビタミンDの投与が必要である。しかし血清Pの コントロールを必要である。

最後に，PTH を測定をいただいたがん研阿部先生初 め諸先生に意謝の意を表します.

千野 次に，演題14の長期血液透析患者に扰壮尚骨代 謝異常の治療，東京女子医大の岡沢先生㧍瀕いいたしま す.

岡沢 血液透析患者に打怕る骨代謝異常は，レントゲ ン学的に 3つのタイプに分けられまして，1つはくる病 性変化を主体としたもの，1つは二次性副甲状腺機能元 進症を主体としたもの，1つは 2 者の共存型でありま す.とのような dialytic bone disease を過去約 3 年に わたり臨床において検討した結果，治療の上で幾つかの 知見を得ましたので報告いたします。

dialytic bone disease の原因はまだ十分に明らかに なったとは言えませんが，ビタミンDの活性化障害が大

図 1

Uitamin $D_{3}$

Dihydrotachysterol
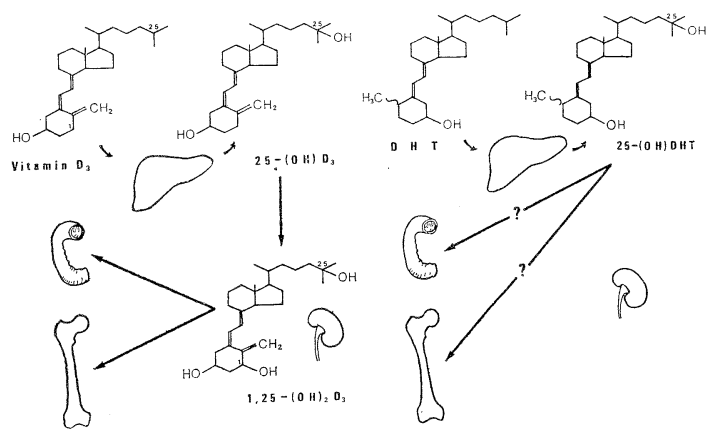

きな部分を占めているととは，周知のことであります。 ビタミンDは肝，督で活性化され，1-25- - $\mathrm{OHD}_{3}$ の形之 なり, 腸・骨を標的臟器として作用を発揮いたします (図 1). 当然治療に当たってわれわれの関心は, 活性 型に向けられましたが，入手は極めて困難でありまし た. そとで， $5.6 \operatorname{trans} 3 \beta \mathrm{OH}$ の形であるディヒドロ タチステロールが肝で 25- $(\mathrm{OH})_{2}$ を受けるなら 1-25$\mathrm{OHD}_{3}$ と立体的に類似な形となることに注目いたしま して, 二次性副甲状腺機能九進症に上る囊董性, 線維性 骨炎の症例飞 DHT を慎重に投与いたしました。

症例は14歳の男子でありまして, 入院時に左大腿骨下 端にCyst 様病変を伴った線維性骨炎が見られておりま す. DHT を投与して 1 年後にての変化は消失し, 中止 1 年後には再び出現しております。ここでわれわ扎は， DHT が肝に扔いて 25- $(\mathrm{OH})_{2}$ を受けるだけで腎の関 与なしに血清 $\mathrm{Ca}$ 值を上昇させ, 二次性副甲状腺機能艺 進症を抑えているのであろうと推察しましたが, 更に症 例在重ねて検討する必要がありました。一般に成人患者 に打ける dialytic bone disease のレントゲン写真は, 線維性骨炎の所見を示すととは余りなく, 大部分は骨脱 灰を主体として扣ります。したがって，治療に当たって は，骨塩量を経時的に定量して経過を追わねばなりませ ん. しかし, 従来のレントゲン写真から計測する方法は 誤差が大きく，信頼性の薄い検查法でありますし，バイ オプシーによって定量するととも，回を重祇るというこ とになりますと困難になりましょう。

そこで, 共同研究者の白須らは, エネルギーの違う 2 線源すなわち $241 \mathrm{Am} ， 125 \mathrm{I}$ を用いた空中法によって骨 図 2
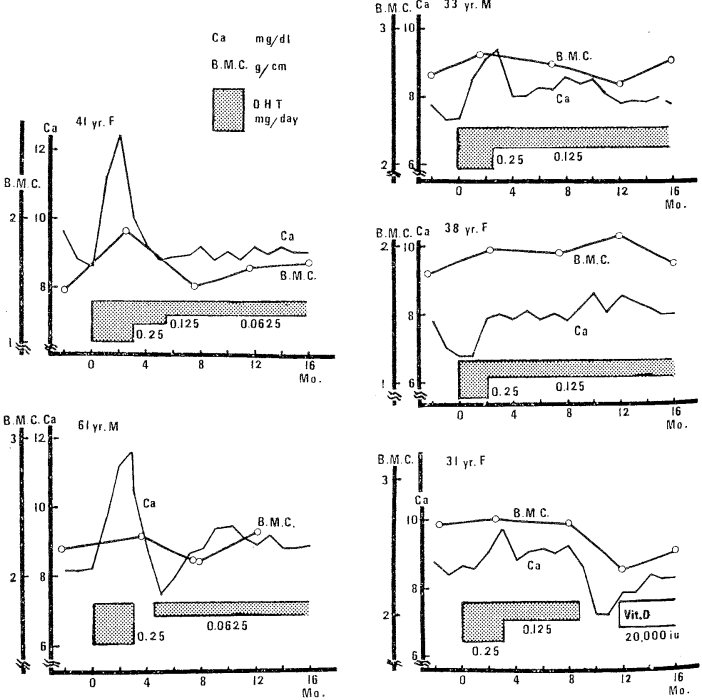
塩量を定量する装置を考案いたしました.

本測定法は再現性の点で極めて優れております．この ような装置を導入して，さきに述べたDHT の治療勃果 について検討を重衫るため，5名の骨代謝異常の認めら れている成人患者に, 臨床的に異所性石灰化のないてと を確かめ,アルミゲル，乳酸 $\mathrm{Ca}$ 剂と共に投与しました。

図 2から明らかなように, DHTを1日0.25mg 投与 したととろ, 血清 Ca 值は 3 週以内に上昇し始め, 骨塩

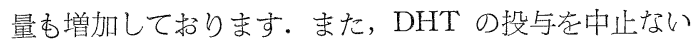
し減量すれば，血清 Ca 值は下降し，それに対応して骨 塩量の減少屯見られました。 DHT の Ca 上昇作用は症 例によって著しく異なっている上, DHT の肝での25$(\mathrm{OH})_{2}$ 反応はフィードバック・コントロールが效かな いため，不注意与えると高 Ca 血症になる危険がありま す.したがって, 投与に当たっては厳重な監視を要しま す.しかし, 注意して投与すれば，血清 $\mathrm{Ca}$ 值を正常域 飞維持し，乙のととが二次性副甲状腺機能立進症の抑制 につながり，長期にわたって骨塩量の減少傾向を抑える ことす可能と思われます，とてろが，DHT の抗くる病 作用は極めて弱いため, dialytic bone disease のすべ てに有効というわけにはまいりません.

図 3 の症例の使用透析液の $\mathrm{Ca}$ 濃度は, $\mathrm{AK}$ ソリタを 水道水で希橎して用いているため， $3.5 \mathrm{mEq}$ 前後と高濃

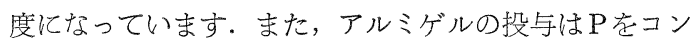
トロールする目的で全例に行なっております．DHT 投 与例の骨塩量が増加ないしほとんど変化がないのに対し て，非投与例では80\%の症例が減少しております。ての ように，比較的高濃度の Ca を擁した透析液で透析して おりまして屯骨塩量の減少が見られるととが明らかにな りましたので，透析液の至適 $\mathrm{Ca}$ 濃度を決定するため に, Ca 濃度の変更を行ないました.

図 3
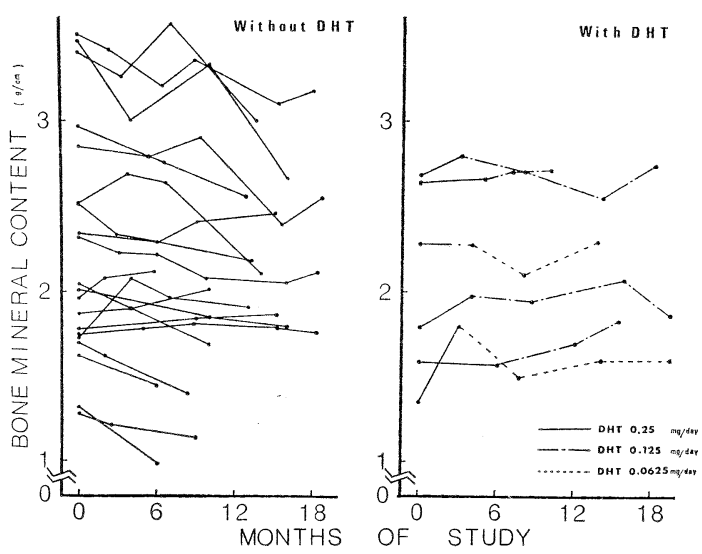

透析液の $\mathrm{Ca}$ の濃度を, 2 名の成人患者に対しては $5 \mathrm{~m}$

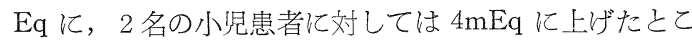
ろ, ハード・ウォーター・シンドロームと思われる悪心, 嘔昍などの不快な症状を呈したため，使用を中止してお ります. その後, 成人患者には $4 \mathrm{mEq}$ の濃度にして, 現 在 3 カ月になりますが, 低 $\mathrm{Ca}$ 血症の改善には至ってお りません。

DHT を投与していない症例では，透析によって血清 $\mathrm{Ca}$ 值を上げてむ，透析終了後 4 時間目には既に前値に 復して打ります（図 4)。すなおち, 透析液の $\mathrm{Ca}$ 濃度 を上げても抗くる病作用については期待できませんし． 血清 $\mathrm{Ca}$ 值を正常化するととすできません．むしろ異所 性石灰化を誘発する恐れが西ります。このような理由で， われわれは透析液の $\mathrm{Ca}$ 濃度を従来より使用してきた濃 度である $3.5 \mathrm{mEq}$ 前後が適切と考元, ビタミンDに関 する研究に集中いたしました。

症例は，28歳の女性であります(图 5)。腎移植を目 的として両側腎摘出を行ない, その後腎移植術を施行し ていますが，数 10 日後には拒絶され，移植腎の摘出が行 われ，無腎となってから約 2 力年を経適しています，血

図 4

図 4 Changes in serum Ca

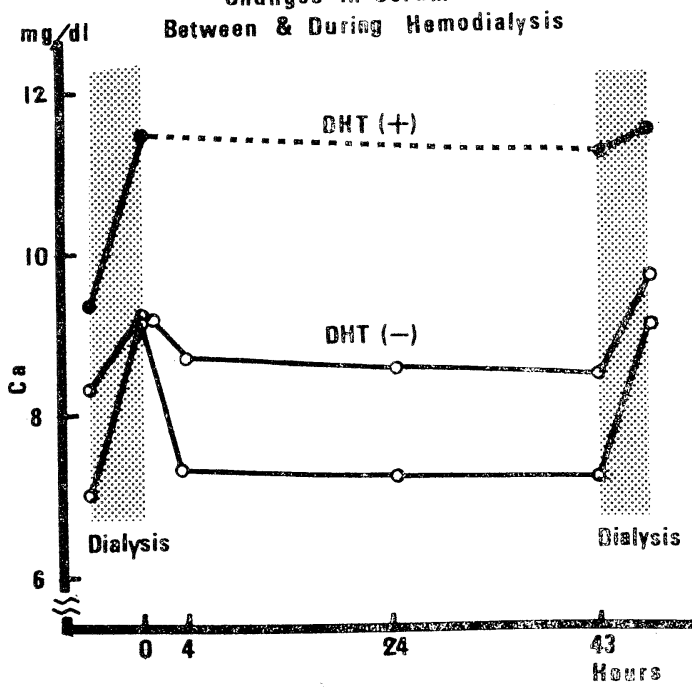

図 5

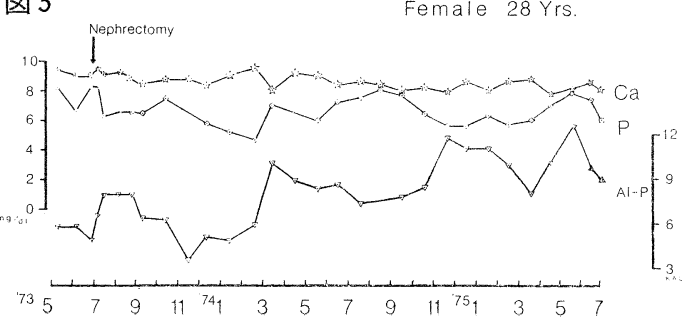


清 $\mathrm{Ca}$ 值は $10 \sim 8 \mathrm{mg}, \mathrm{P}$ 值は 6〜8mg，アルホスは上昇 傾向でありますが，ほぼ正常域にあります．とのような 無腎症例は，ビタミンDが肝，筲で代謝され，1-25$\mathrm{OHD}_{3}$ 亡なって初めて作用を発揮すると考えていた今 までのわれわれの常識には当てはまらないものでありま す.

との症例から，次の3つのととが推测されます，1つ は, ビタミンDの最終活性型の経路が腎以外の臟器にあ 存在するのではないかということでありまして，とれは 文献的には否定されれております. 2 つ目は,ビタミンDの 活性型の整的臟器のリセプターは，䈌密な意味での特異 性がないため，ビタミンDのメタボライトやアナローグ でもリセプターと親和性があり，活性型ビタミンDと同 様の作用压認めることができるというととであります。 また三つ目は，まだ不明のメカニズムがあって骨代謝を 維持しているのではないかなどであります。

この二番目の仮定の下にほほとんど腎機能が廃絶した 血液透析患者に対してビタミンDの投与を武みました。 さきにX線写真で示した囊腫性線維性骨炎の14歳の男子 の症例ですが（図6)，DHT 投与中止後 Cyst 樣変化 が再び出現し，大腿骨の変形す著明となったためビタミ ンDを投与いたしました。2,000単位近くまで上界して いたアルカリ・フォスファターゼは50単位以下に下がっ

図 6

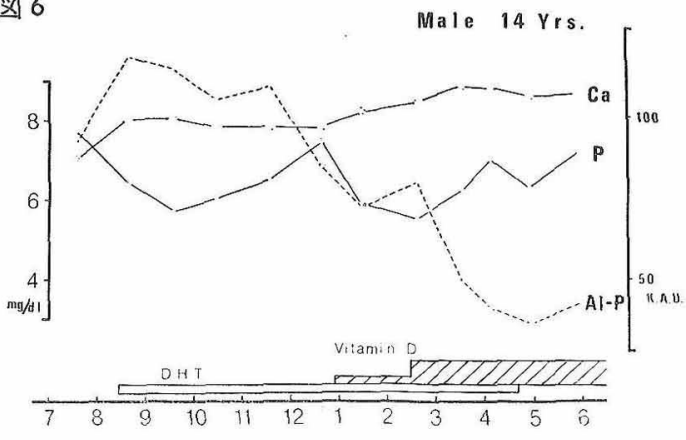

図7

Effect of Vitamin D

on Bone Mineral Content

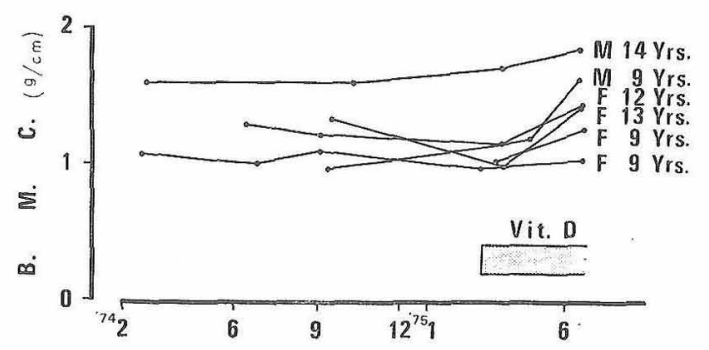

ております。，血清 $\mathrm{Ca}$ 值，骨塩量の上暴增加む認めら れ，パラサイロイドホルモンは $11 〜 6 \mathrm{Ng}$ に下降してお りました。

6 名の小児患者のうち, 図7一番下の 9 歳例を除いて 全例にビタミンD起投与いたしました。ビタミンDの投 与によって骨塩量は堌加しております。とのような例 は，1名ではあり劣すが，成人患者化も認められていま す.

図 8 は 9 歳の無尿加つ偏腎摘出されている男子透析患

図 8

Efrect of Vitamin D in Hemodialysis Patient

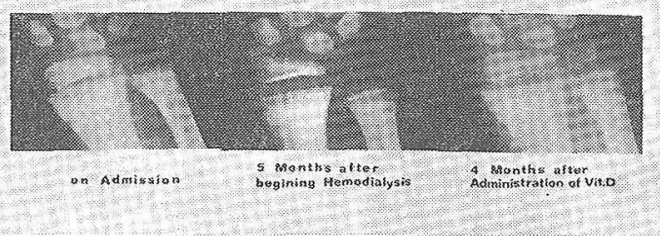

者の右于関節であります。橈骨末端部にくる病性変化が 認められます．血液透析によって栄養状態が好転すれば そのようなくる病性变化す改善するあのと考元, 5 力月 間アルミゲルと乳酸 $\mathrm{Ca}$ 剂のみで経過を見ておりました が，図に示すように骨病変は悪化しておりました，そこ で，1〜3万单位のビタミンDを投与したところ，4カ 月後には骨化が起き, 悪化した橈骨下端の病変は改善 し，入院時の状態にまで回復しております.

ビタミンDは肝，輎を経て水酸化を受け，1-25一 $\mathrm{OHD}_{3}$ となって作用を発捙するというととが動物 実験 によって明らかれされて以来, われわれも專ら活性型の みに注意を注ぎ，1-25- $\mathrm{OHD}_{3}$ のアナローグであるDHT について検討を加㫕てまいりました。しかし，無腎であ

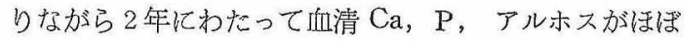
変化なく保持されている症例に遭遇し，ビタミンDの薬 理作用について改めて考え直し, 腎機能の廃絶した患者 に対してあビタミンDの投与を試みております。その結 果, くる病変化及び二次性副甲状腺機能九進症による病 変の血液生化学的また X 線学的な改善が認められまし た.このととは，高価なために現実には入手困難な 125- $\mathrm{OHD}_{3}$ ，あるいはまだ動物実験の段階である $1-\alpha-$ $(\mathrm{OH}) \mathrm{D}$ に頼らずとあ，ビタミンDによる治療がある程 度可能であるというととでありまして，今後な打症例を 重ねて検討していきたいと考えております.

最後に，パラサイド。ホルモンを测定していただきま した菓大老人科岡野先生に深謝いたします。

千野 続いて, 演題15, renal osteodystrophy のレ 
線学的ならびに病理組織学的検索, 兵庫医大の若菜先生 お願いします。

若菜 最近, 人工透析療法の普及により, 腎不全に陥 った患者の延命効果は著しい, しかしその反面, 本来の 腎譏能が改善しないために，主として Ca 代謝障害に基 うく症状としての骨変化, すなわち骨軟化, 線維性骨 炎, 骨粗鬆, 骨硬化, 軟部異所性石死化等が生ずると言 われている。 今回，われわれはかかる症例について，主 として定量的見地加ら, レ線学的, 組織学的並びに生化 学線検索を行ない, 若干の知見を得たのでととに報告す る.

症例は，兵庫医大淀院他 4 施設にて血液透析療法を受 けている慢性鳌不全症の成人患者 122 名, うち男性 82 名 女性40名について, 更にそのうち66例の 1 年経過観察に ついてレ線学的及び生化学的检索を行なった。

透析方法は週 $2 \sim 3$ 回で, 透析液中のCa 濃度は6mg/ dI の市販の液を使用している, 筒不全に陥った後, 最 短 1 力月, 最長 47 力月の血液透析潦法を受けている.

われわれの症例で骨レ線像に明らかに認められた変化 は 3 例のみで，いずれもか軟部異所性石厕化像を呈して いた. 右足 5 趾中足骨骨 頭部左 4 指 PIP 関節部大腿部 血管壁の石灰化であります。

レ線上の bone density の判定には，第 2 中手骨正面 像における長軸中央部の骨幅と皮質幅の比をむって表わ † Nordin $の$ hand score $\measuredangle$ Nordin $の$ lumber score をやや修正した, 第 3 腰椎側面像に拎ける椎体後縁と中 央部の高さの比をるって表わした，われわれがさき行 なった同じ方法を用いた健康人によるコントロール群を 基準に，年代別の比較㭘討を行なった.

透析期間と bone density の関係は，透析期間が長 期に及ぶほど density わずかに減少する傾问にあった。

bone density について年代別に計测し, 全症例の 60 \%が正常であり，25\%が減少していた。

1 年間に叔ける density の推移は，70\%には変わり なく, 約 $25 \%$ density の減少が見られた。特に hand score に，その著しいのは内骨膜吸収が進行しているか を疑わせる。

骨レ線検查前 3 カ月間の血清 $\mathrm{Ca}, \mathrm{P}$, アルカリ・フ オスファターゼ值をみると, 低 $\mathrm{Ca}$, 高 $\mathrm{P}$ 血症を呈し, アルカリ・フォスファターゼ值は正常域にあった。た だ，アルカリ・フォスファターゼ值上昇例には, hand scroe の低下が認められた以外は，上線像との間には相 関性がなかった。

剖検例について，血液透析療法にもかかわらず不幸に して死の転帰をとった 9 例より採取した腸骨について，
組織学的並びに生化学的検索を行なった。脱灰嘌本につ いて Beck 法による骨梁比を計测し，同時にその 組織 像をあ観察した。 また，非脱灭標本を Masson Goldner 染色し，その識別により骨稜における類骨組織の比を計 測した。一方, 腸骨骨稜の一部在扊化し, 死化重量亚び にその Ca 量を計测した.

督不全症の脱灰染色標本で，著明な骨薮縮を呈した一 例である，その骨梁比は10\%であった。

図 1(A)は，骨梁比と年齢との関係を表わしたもので ある、斜線は正常の骨梁比を示すむので, 简不全例のそ れは斜線付近に散在している。すなわち，それほど骨菱 縮はない。また，灭化重量と骨梁比を見ると，図2のご とく, その関係は比例していた。

28歳, 男性の一例の骨吸収像では骨稜は線状に侵蝕さ れ，乙の部には多核性の矽骨細胞と線維化像を呈してい

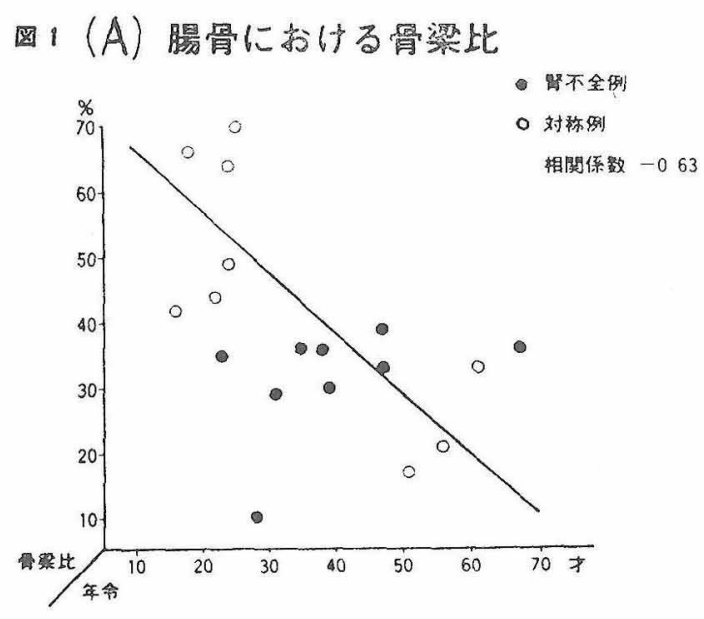

図 2 骨量 $1 \mathrm{~cm}^{3}$ における灰化重量と骨梁比

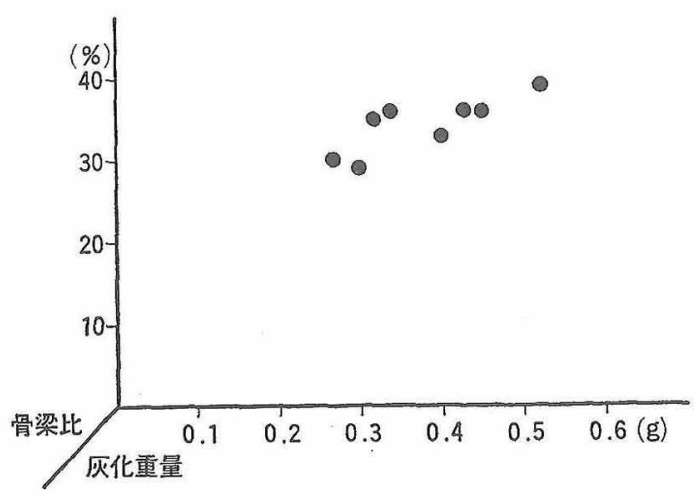


た. 9 例のうち著明な 3 例のほか，計 7 例にかかる所見 を見た. しかし, 剖検時, 副甲状腺の形態学的変化は認 められなかった。

非悦灰後, Masson Goldner 染色を施した標本では

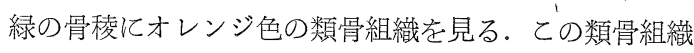
は，骨吸収像を呈している部位における類骨で，すなわ ち脱灰により生じた類骨組織と考えられる.

図1（B）は骨稜にお於類骨組織の比，すなわち， Osteoid 比之年齢との関係を表わしたあのである.われ わが計測した健康群のそれは $8 \%$ 以下であったが，腎不 全例においては 4 例に高值を示した.

一定の骨容積としての灭化重量を小さな染とし, 扊化 中 $\mathrm{Ca}$ 量を斜線の部分として図式化すると, 健康群と比 較して, 明らかに Ca と扊化量の比の低下が 4 例に見ら れた。

ま之め 透析患者 122 名に拈けるレ線学的並びに生化 学的所見よりわれわれの症例で骨レ線像に明らかに認め られた変化は, 軟部異所性石灰化像の 3 例のみであっ た．これに関して欧米の報告例ではかかる変化が著しい のに反して，我が国ではわれわれ同様少いようでありま す.

\section{困 1（B）腸骨における類骨比}

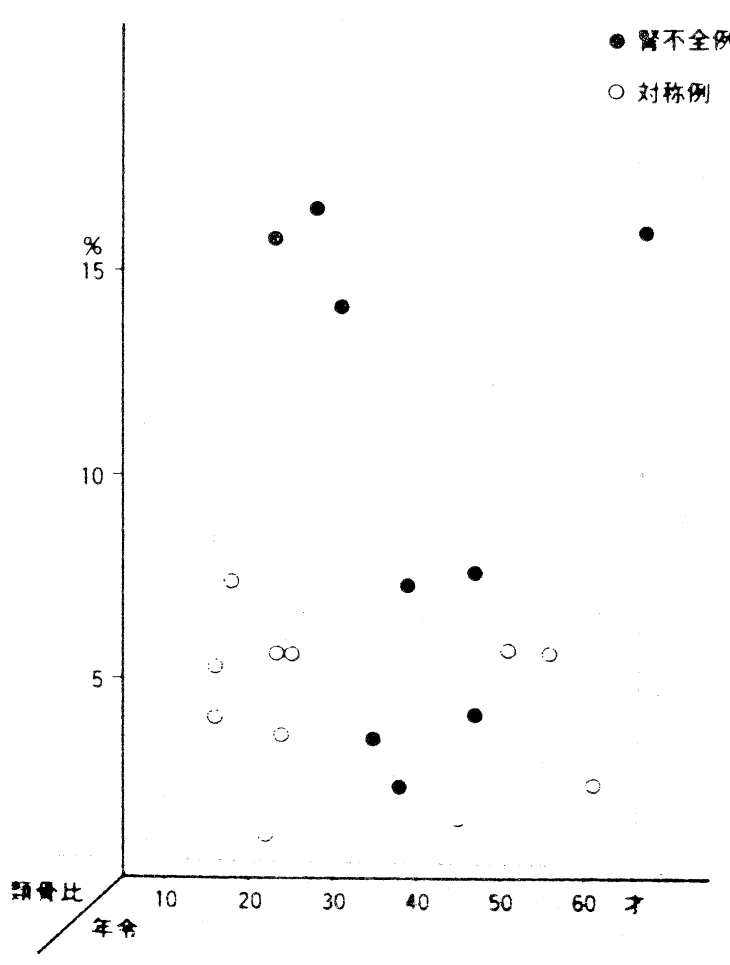

次に，透析期間が長期に及ぶほど，レ線上の bone density の減少，すなわち骨皮質の菲薄化，骨稜の脆弱 化の傾向にあった。 また, bone density は, 全体とし て女性は男性に比べて high density の傾向にあった が，乙れはホルモメールな因子によるとてろが大きいか と屯考えられる、レ線上約 $25 \%$ low density が見ら れたが，乙れは骨粗鬆によるすのか，骨軟化によるもの か，あるいはまた線維性骨炎によるものかの判別が困難 で, この辺りにレ線学的方法では限度があり, 更に詳細 に追究するためには組織学的検索が必要であろう。しか し, 種々な事情により, 患者すべてに骨生検を行なうこ 之は困難である.われわれは, 不幸にして死の転帰を之 つた 9 例より採取した腸骨について組織学的検索を行な い，全般的に軽度の骨萎縮 が，また 7 例には骨吸収像 が，更に 4 例には類骨組織の異常な増加が認められた。 これらは，現在 renal Osteodistrophy の成因として言 われているビタミンD抵抗性により, 更に二次性副甲状 腺機能立進症によって生じたものと思われる.しかし， 全例に低 $\mathrm{Ca}$, 高 $\mathrm{P}$ 血症というアンバランスな状態が続 くにあかかわらずかかる変化を呈していない剖検例にも 認められているととは, 血液透析療法が有効に㗢いてい るためか，あるいはまた何らかの因子が作用しているあ のか，更洎究する必要があると考えます．

千野 続いて, 演題16の慢性腎不全に括ける二次性副 甲状腺機能六進症の研究, 北里大学の浅野先生和願い儿 ます。

浅野 慢性腎不全患者及び長期人工透析例に扔いてし ばしば二次性副甲状腺機能え進症を認めますが， その $\mathrm{Ca}, \mathrm{P}$ やビタミンD代謝との臨床像との関係を見た総合 研究は，まだ十分なされているとは言えないと思いま す.そこで,われわ机は過去数年来にわたりまして, 北里 大学内科及びサテライト病院に通院する約 150 名に上る 患者の血清 i PTH 濃度及び骨レ線像を， 6 カ月間隔で 追究してまいりました，また同時に，血清電解質，血液 化学, 必要に応じて骨生検やラジオアイソトープ, Ca, Pの骨咬収像の追究, 死亡例にあっては骨や副甲状腺の 組織像等の検討を, 内科, 放射線科, 外科, 整形外科, 内分泌研, 病理等各科の連携の下に, 立体的に腎不全像 をとらえようと努力してまいりました.

今回は, 透析直前の慢性腎不全患者 15 例及び 1 年以上 4 年未満の間透析を受けた患者36例の, 血清 $\mathrm{PTH}$ 濃度 と骨レ線像との変化との関連に関して報告いたします.

方法は, 血清 iPTH の測定は, 田中らの方法におい て行ない，透析例に抢いては透析直前に採血をいたしま した、ボーン・サーベイは, 頭部側面, 両手正面, 腰椎 
側面，骨盤——股関節を含みます一一正面，両膝関節正 面, 脑部正面にて行ないました。レ線上の骨変化の判定

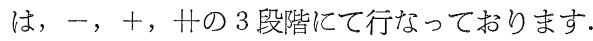

表 1 , 正常人 19 歳より 40 歳にわたる 27 名の血清 PTH 濃度を示したすのです，約半数の 13 例では $0.1 \mathrm{Ng} / \mathrm{ml}$ 以 下, 14 例では, $0.1 \sim 0.4 \mathrm{Ng} / \mathrm{ml}$, 平均 $0.14 \pm 0.11 \mathrm{Ng} / \mathrm{ml}$

表 1 Serum Concentrations of Immunoreactive Parathyroid

Hormone (iPTH) in Normal Subjects (Mean \pm S.D.)

\begin{tabular}{lrl}
\hline Total & 27 & cases \\
Undetectable & 13 & Less Than $01 \mathrm{Ng} / \mathrm{ml}$ \\
Detectable & 14 & $0.14 \pm 0.11 \mathrm{Ng} / \mathrm{ml}$ \\
\hline
\end{tabular}

表 2

Serum Concentration of iPTH in Chronic Renal Failure $\mathrm{Ng} / \mathrm{ml}$ (Mean \pm S. E. )

\begin{tabular}{|c|c|c|c|c|}
\hline \multirow{2}{*}{$\begin{array}{l}\text { Before Dialysis } \\
\text { (Ccr. }<10 \mathrm{ml} / \\
\text { min) }\end{array}$} & \multicolumn{2}{|r|}{ Dialysis } & \multicolumn{2}{|c|}{ Patients } \\
\hline & 6 months & 1year & 2years & 3years \\
\hline $3.84 \pm 0.60$ & $\begin{array}{l}3.98 \pm \\
1.13\end{array}$ & $\begin{array}{r}3.95 \pm \\
0.93\end{array}$ & $\begin{array}{r}3.96 \pm \\
1.36\end{array}$ & $\begin{array}{r}6.70 \pm \\
2.88\end{array}$ \\
\hline$N=15$ & $N=16$ & $N=18$ & $N=16$ & $N=7$ \\
\hline
\end{tabular}

図 1

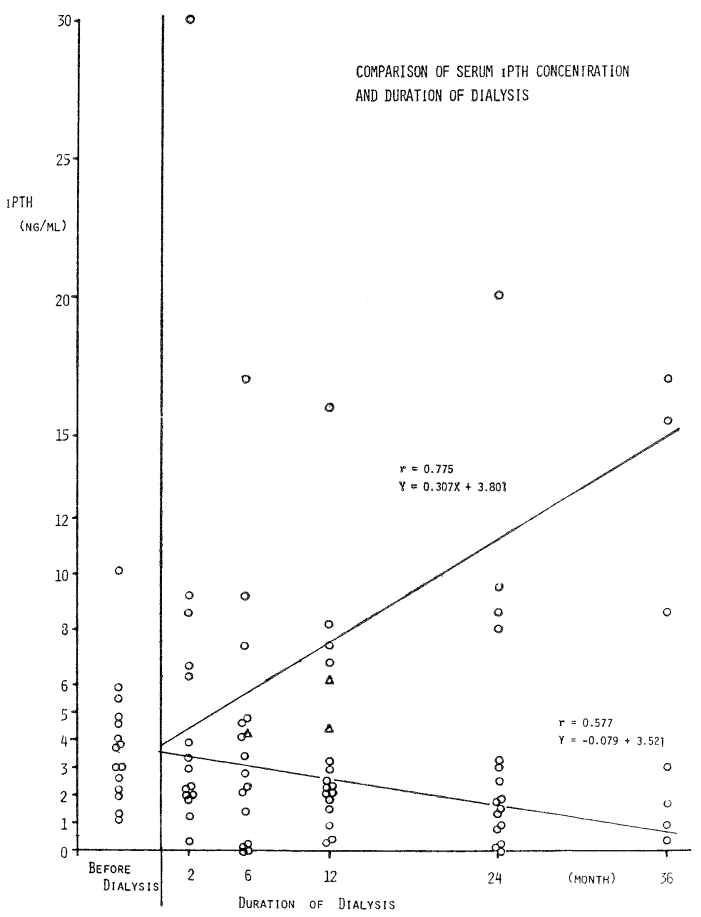

ありました。

一方, 透析開始直前, クレアチニン・クリアランス $10 \mathrm{ml} / \mathrm{min}$ 以下のグループでは, $3.84 \pm 0.60$ 高値を示 し，正常值を示す例は 1 例あありませんでした.

次に，透析群に求いては， 3 年透析群が $6.70 \pm 2.88$ 上 他より高值を示した以外，平均值は極めて透析前值の屯 のと近似を示しております（表 2).ただ， 3 年透析群 に招いても standard error がごらんのと伺り大きく, 他の群との統計学的な有意差は得られませんでした，

ことで各測定值を透析期間に対してプロットします と，図1のごとくなります，血清iPTHは，透析開始に より前值に比して正常值まで復すすのがあります．正常 值の線がちょっと見にくいのですが，0.5 以下です．透 析前には 1 例むございませんが，透析開始後 1 力月， 6 カ月, 12 力月, ごらんのように正常值に復してくるすの がでざいます。その反面，逆に高值を示してくるものが 中に执いて見られます，最近 Johnson らは，長期透析 により血清 iPTH 濃度は正常に復するとの報告を行な っていますが，われわれの成績からは必ずしる正しくな いと思われました。

更に, iPTH 高值群と比較的低值群とに分ける目的 で，便宜的に透析前值の平均值約 $4.0 \mathrm{Ng} / \mathrm{ml}$ より高い 群と低い群とに 2 大別を行なってみました，それぞれに つき透析期間との相関関係を求めたとてろ，図のような 線が引けます。すなわち，高值群では，透析期間と共に 上勢を示し, $\mathrm{Y}=0.307 \mathrm{x}+3.801, \mathrm{r}=0.775$ なる一次式の 相関関係を示しました。低值群では, $\mathrm{Y}=-0.079 \mathrm{x}+3$. $521, r=0.577$ と透析期間と共にやや低くなるような傾 向を示しております。

表 3

ROENTGENGGRPHICAL CHANGES IN DIALYSIS PATIENTS

[ $\mathrm{iPTH}>4.0$ ]

\begin{tabular}{|c|c|c|c|c|c|c|c|c|c|c|}
\hline \multirow[b]{2}{*}{ Patient } & \multirow[b]{2}{*}{ Age } & \multirow[b]{2}{*}{$\operatorname{sex}$} & \multirow{2}{*}{$\begin{array}{l}\text { Duration of } \\
\text { Pialaksjis }\end{array}$} & \multicolumn{6}{|c|}{ Roentgenographical Changes } & \multirow{2}{*}{$\begin{array}{c}\text { Serum iPTH } \\
(\mathrm{ng} / \mathrm{ml})\end{array}$} \\
\hline & & & & Deminera & lization & $\begin{array}{l}\text { Subpe } \\
\text { bone }\end{array}$ & $\begin{array}{l}\text { riosteal } \\
\text { erosion }\end{array}$ & Osteoscle & rosis & \\
\hline 1. & 32 & M & 3.0 & $\begin{array}{c}1 \\
++\end{array}$ & II & $\begin{array}{l}1 \\
-\end{array}$ & II & I & & $17.0 / 2.5$ \\
\hline (2) & 19 & M & 3.5 & - & - & - & + & - & - & 15.5 \\
\hline (3) & 30 & M & 3.0 & + & t+ & + & + & t+ & - & 11.1 \\
\hline 4. & 49 & $\mathrm{~F}$ & 2.5 & t+ & tt & - & - & - & - & 9.5 \\
\hline 5. & 33 & M & 2.5 & + & + & - & - & - & - & $20.0 / 0.1$ \\
\hline 6. & 39 & $\mathrm{~F}$ & 2.5 & + & + & - & - & - & - & 8.6 \\
\hline 7. & 30 & M & 2.0 & ++ & ++ & - & - & - & - & 8.0 \\
\hline 8. & 38 & M & 1.5 & t+ & +t & - & - & - & - & .6 .8 \\
\hline (9) & 21 & M & 1.5 & - & + & - & + & - & - & 16.0 \\
\hline 10. & 49 & M & 1.5 & t+ & +t & - & - & - & - & 7.4 \\
\hline 11. & 64 & $\mathrm{~F}$ & 1.5 & ++ & ++ & - & - & - & - & 14.5 \\
\hline 12. & 55 & $\mathrm{~F}$ & 1.5 & ++ & ++ & - & - & - & - & 4.4 \\
\hline 13. & 62 & F & 1.5 & ++ & t+ & - & - & - & - & 6.1 \\
\hline (14) & 28 & F. & 1.0 & - & - & - & + & - & - & 8.1 \\
\hline 15. & 58 & M & 1.0 & t+ & ++ & - & & - & & 4.2 \\
\hline
\end{tabular}


続いて，透析期間が 1 年以上 4 年未満の患者における レ線上の骨変化を示したものが，次の表です。

表 3 は PTH 高值群，すなわち $54.0 \mathrm{Ng} / \mathrm{ml}$ 以上を示 した群に打ける骨変化を示したものです。骨レ線上の変 化の初め I，II のというのがありますが，Iの方は透析 開始前の変化，II というのは透析期間後の変化を示して あります。透析期間は左から 4 例目に書いてあります. デミネラリゼーションは，多くの症例では透析開始時よ り見られましたが，中では透析開始後増強したあのああ ります。一方，特にセカンダリーハイパーパラサイロイ ディズムスとして特徴的な所見として言われるコーチカ ル・エロージョン,オステオスクレローシスなどが笔げら れますが，乙れらの変化したものは 1 年以上 4 年未満の 透析例36例中 4 例に执いて見られました。この 4 㤡は， いずれもただいま表に見せているグループの中に入り， PTH 屯かなりの高值を示しています。年噛的にはいず れも30歳以下の若年の例に見られたととが特徽的と言え ましょう。逆に, デミネラリゼーションの方は高齢者に 多く出てきており，加龄による变化の加味も考えなけれ ばい讨ないと考えております。

次は $\mathrm{PTH} 4 \mathrm{Ng} / \mathrm{ml}$ 以下の群で（表 4)，この群はダ イアリシス期間に関係なくエロージョンを見た例はな く，かつデミネラリゼーションを示す例も比較的少ない ようです.

これらの所見を認められました 4 例とも，アルカリ・ フォスファターゼ值は高く，15.0,26.6, 16.8,32.0,血清 PTH 6それぞれ 15.5,11.1, 16.0,8.1 と異常高值を示

表 4

ROENTGENOGRAPHICAL, GHANGES IN DIALYSIS PATIENTS

$[$ iPTH $<4.0$ ]

\begin{tabular}{|c|c|c|c|c|c|c|c|c|c|c|}
\hline \multirow[b]{2}{*}{ Patient } & \multirow[b]{2}{*}{ Age } & \multirow{2}{*}{ Sex } & \multirow{2}{*}{$\begin{array}{l}\text { Duration of } \\
\text { Dialysis } \\
\text { (years) }\end{array}$} & \multicolumn{6}{|c|}{ Roentgenographical Changes } & \multirow{2}{*}{$\begin{array}{c}\text { Serum iPTH } \\
(\mathrm{ng} / \mathrm{mI})\end{array}$} \\
\hline & & & & Deminer & ization & $\begin{array}{l}\text { Subpe } \\
\text { bone }\end{array}$ & $\begin{array}{r}r \text { riosteal } \\
\text { erosion }\end{array}$ & Osteosc & lerosis & \\
\hline 1. & 36 & $\mathrm{~F}$ & 3.5 & + & t+ & - & . & - & $=$ & 1.0 \\
\hline 2. & 30 & M & 3.0 & - & +* & - & - & - & - & $1.2 / 3.0$ \\
\hline 3. & 40 & $\mathbf{F}$ & 3.0 & - & - & - & - & + & + & 0.4 \\
\hline 4. & 25 & M & 2.5 & - & - & - & - & - & - & 1.5 \\
\hline 5. & 50 & M & 2.5 & ++ & + & . & - & - & - & 3.0 \\
\hline 6. & 49 & $\mathrm{~F}$ & 2.5 & + & + & . & $=$ & - & - & 2.3 \\
\hline 7. & 34 & M & 2.0 & + & + & . & - & - & - & 0.8 \\
\hline 8. & 48 & M & 2.0 & - & ++ & - & - & - & - & $1.9 / 1.8$ \\
\hline 9. & 38 & M & 2.0 & - & ++ & - & - & - & - & $2.5 / 0.1$ \\
\hline 10. & 64 & M & 2.0 & ++ & ++ & - & - & - & - & 0.3 \\
\hline 11. & 58 & M & 2.0 & + & + & - & - & - & - & 1.9 \\
\hline 12. & 33 & M & 1.0 & - & - & $:$ & - & - & - & 2.2 \\
\hline 13 & 33 & M & 1.0 & $=$ & $=$ & - & - & - & - & 2.1 \\
\hline 14. & 49 & M & 1.0 & ++ & $+*$ & - & - & - & - & 0.4 \\
\hline 15. & 38 & $M$ & 1.0 & - & * & - & $:$ & - & - & 0.9 \\
\hline 16. & 35 & M & 1.0 & - & $*$ & - & - & - & * & 1.9 \\
\hline 17. & 30 & M & 1.0 & - & & - & & - & & 2.1 \\
\hline 18. & 34 & M & 1.0 & - & & - & & - & & 2.3 \\
\hline 19. & 23 & $\mathrm{~F}$ & 1.0 & + & + & - & - & . & - & 3.2 \\
\hline 20. & 33 & F & 1.0 & - & & - & & - & & 1.5 \\
\hline 21. & 53 & M & 1.0 & ++ & $4+$ & $=$ & - & - & - & 2.9 \\
\hline
\end{tabular}

しました。乙てれら副甲状腺機能宇進症の著明な例では， 副甲状腺亜全摘手術による外科的な手術方法等を積極的 に行なうべきと考えられました。

まとめ 慢性婜不全患者非透析群では，全例に拉いて 血清 $\mathrm{PPTH}$ 值の上昇を認めましたが， mean は約 4.0 $\mathrm{Ng} / \mathrm{ml}$ でほぼ 1 〜 の間でありました。透析患者群に 扔いては，透析期間において応じ不変，又は減少を示す グループと，増加を示すグループとに分けられ，増加を 示すグループでは透析期間との間に一次の相関関係が認 められました，減少を示す群の中には正常值を示す例屯 含まれておりました，血清 PTH 高值群，すなわち 15 例中 4 例に执いては，レ線上に subperiosteal bone erosion osteosclerosis を示し， かつ血清アルカリ・フォ スファターゼ值及び血清 $\mathrm{iPTH}$ 濃度も他に比し異常に 高い值を示して扔りました。

腎不全に㧍ける血清 $\mathrm{PTH}$ レベルは高值を示しまし たが，目下のところ，乙の高值に対するいわゆるラジオ イムノアッセイ法による方法論的問題点, 又は副甲状腺 内で合成されたホルモンと血中ホルモンが異なるとか， いろいろな問題点が多く，難題を抱えておりますが，わ れわれの測定法でも，常に血清 i PTH 濃度が $4 \mathrm{Ng} / \mathrm{ml}$ 上を示す場合には骨変化が頻発し, 続発性副甲状腺機能 立進症に対する何らかの治療を必要とするような例が多 くあるととがわかりました。

千野 最後の演題17の慢性腎不全患者の骨変化につい て，国立仙台病院の鳥越先生打願いします。

鳥越 私たちは, 慢性腎不全患者のうち, 透析導入前及 び短期腹膜透析の症例の骨レ線像, PTH 血液生化学所 見，非脱灰標本の病理組織像を検討したので報告する.

対象は，仙台腎センターの慢性腎不全患者で，骨生検 27 症例のうち 16 例で（表 1)，その内訳は，透析導入前

表 1

\section{症 例}

\begin{tabular}{|c|c|c|c|c|}
\hline & 年令 & 透析前 & 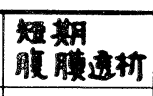 & 計 \\
\hline 男 & $\begin{array}{l}214 \\
269 x \\
2\end{array}$ & $6_{\text {例 }}$ & $7_{\text {例 }}$ & $13_{|k| 1 \mid}$ \\
\hline 女 & $\begin{array}{l}26 x \\
\sim 46 \pi\end{array}$ & 2 & 1 & 3 \\
\hline 計 & & 8 & 8 & 16 \\
\hline
\end{tabular}


Dもの 8 例，短期腹膜透析例 8 例で， 2 力月と 1 力月の 透析期間各々 1 例のほかは，2週間前後の透析である。 年龄は21歳から69歳, 平均39歳で, 男13例, 女 3 例であ る.

これらに腸骨生検による病理組織，骨レ線像，parat一 hormone，r血液生化学検查等の検討を行なった。 PTH は，北里バイオケミカル・ラボラトリースの測定で，正 常值は $0.5 \mathrm{Ng} / \mathrm{ml}$ である. 骨生釱は右腸骨より行ない 非脱灰標本は厚さ $80 \mu$ でマイクラジオグラムをとり, 更に $20 \mu$ で HE 染色を行ない，併せてテトライサイク リン, ラベリングも観察し，脱灰標本は Elartica-Goldner 染色を用いた。レ 線学的観察は, 頭蓋骨, 脊椎, 骨盤，手指骨，足指骨，滕部で行なった。

病理組緇所見では，まず症例を供覽する，症例は46歳 $9 \mathrm{CGN}$ 女子で，昭和50年 1 月20日当腎センターに入院 し，透析導入前飞骨生検を行なった，血床検査战績は， 赤血球169万，ヘマトクリット15\%，クレアチニン。ク リアランス $4.4 \mathrm{ml} / \mathrm{min}, \mathrm{Ca} 7.2 \mathrm{mg} / \mathrm{dl}, \mathrm{P} 5.5 \mathrm{mg} / \mathrm{dl}, \mathrm{BU}$ $\mathrm{N} 86 \mathrm{mg} / \mathrm{dl}, \mathrm{PTH} 6.6 \mathrm{Ng} / \mathrm{ml}$ であった。

マイクロラジオグラムでは, 図1のでとく, 骨稜の表 面は著しく不規則であり，いわゆる osteocystic osteolysis 屯見られる。

同部位を非脱灭標本のHE 染色で見ると，図 2 の上の 方では，石灰化骨の表面は凹凹が激しく，その上に幅広 いオステオイドが覆って拈り，オステオマレーシアの所 見が見られる。他方，下部では，滑らかな石扊化骨に薄 いオステオイドが見られる。

図 3
とれをテトラサイクリン，ラベリングで見ると，シャ ープな取り込みは図 3 下部の滑らかな薄いオステオイド 部に見られ，スライド上部のえぐれた幅広いオステオイ ド部では不解明である。

図 1

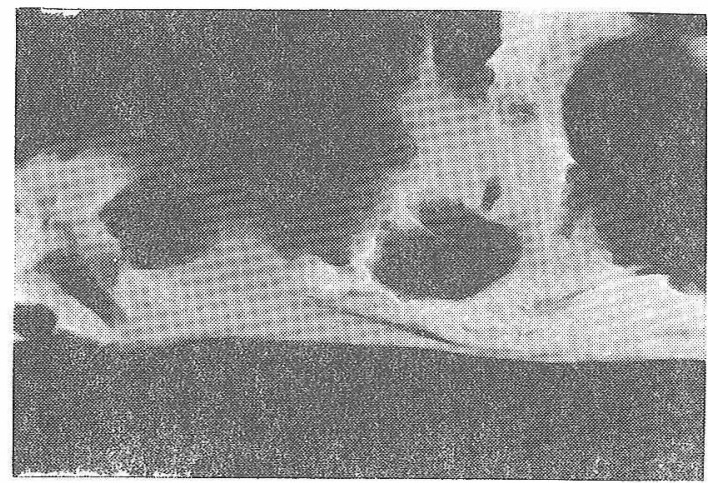

圈 2

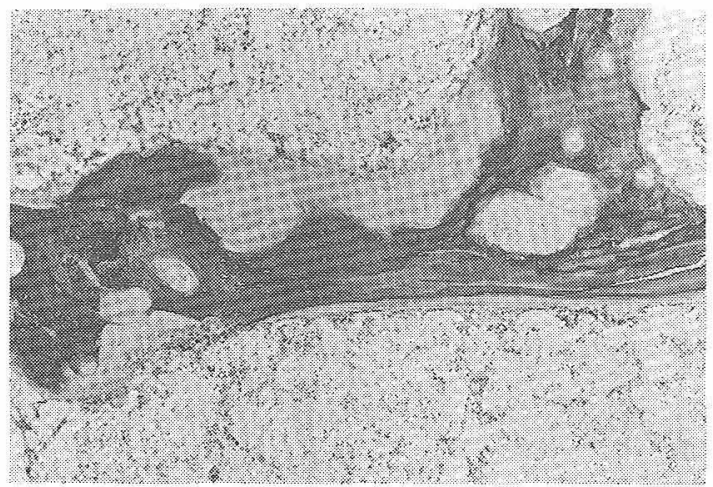

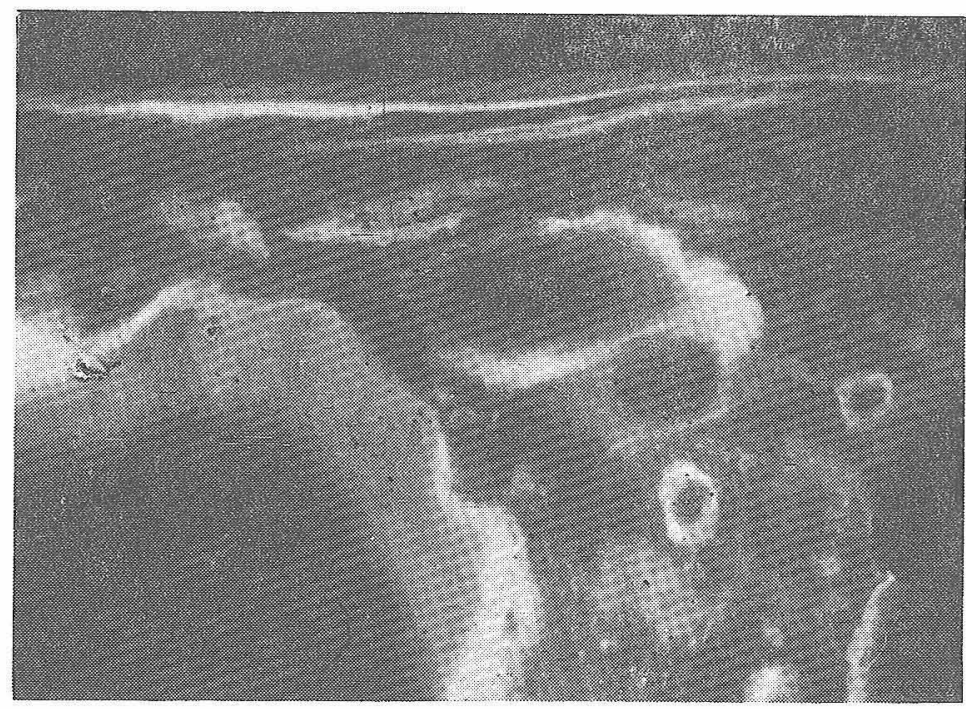


図 4

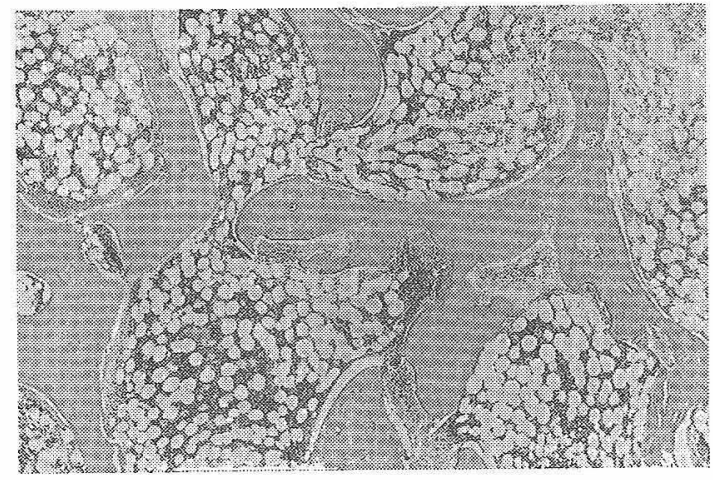

Bone AREA

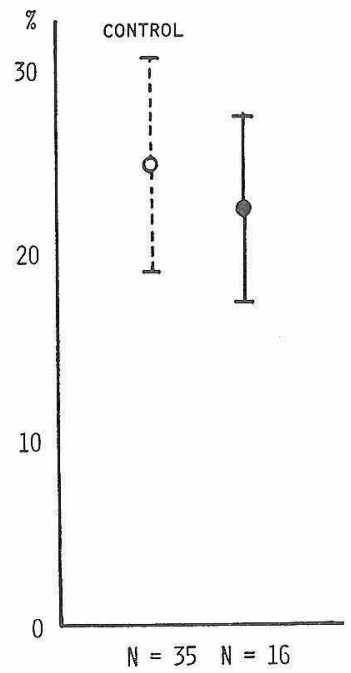

Total Surface Area

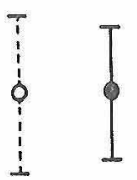

2

0

$$
N=35 \quad N=16
$$

[ 5

図 6
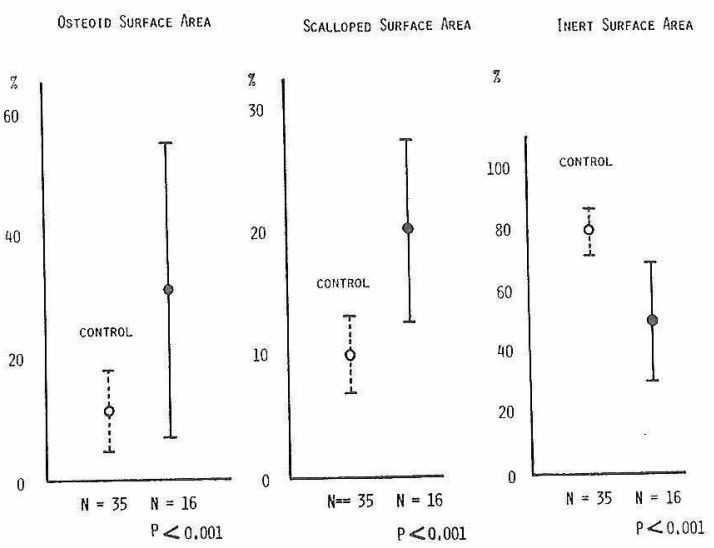

\section{図7}

PTH

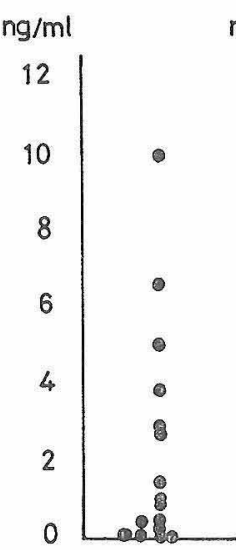

$\mathrm{mg} / \mathrm{dl}$

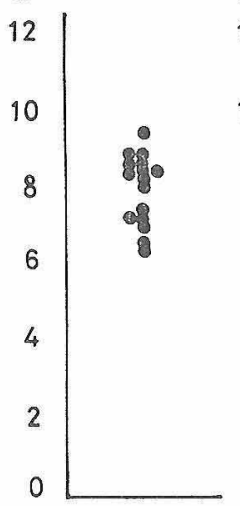

$\mathrm{mg} / \mathrm{dl}$

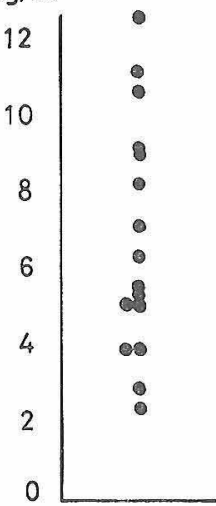

図 8

Bone AREA - PTH

BA \%

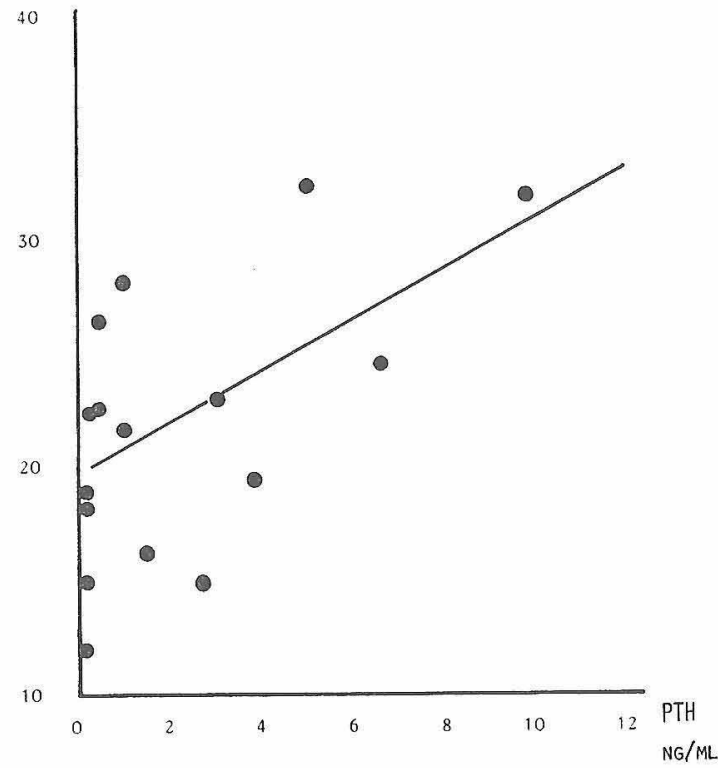


他の部位では，図40ように樑くえぐれた骨吸収部位 の先端には, osteocleasten が見られ，線維組織による 置換むあり，二次性副甲状腺機能六進症を思わせる所見 であった。

また, いわゆる tunnelling resorption は16例中 9 例 に見られ, osteocytic osteolysis 屯16例中 9 例に見ら れた（図4).

次に，16例に非脱灰標本の組織学的定量を行なった. コントロールは東北大整形外科教室のあのを使用した。

図9

Total SURface Area - PTH

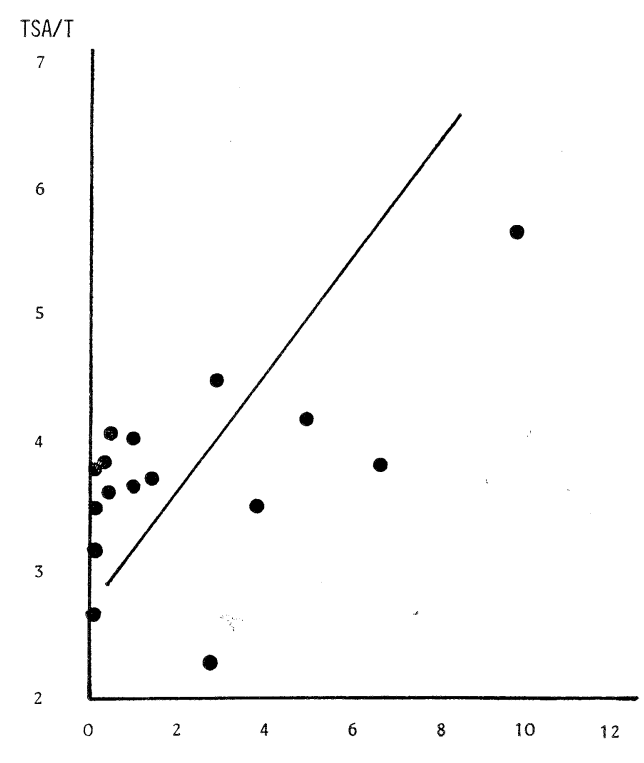

図10

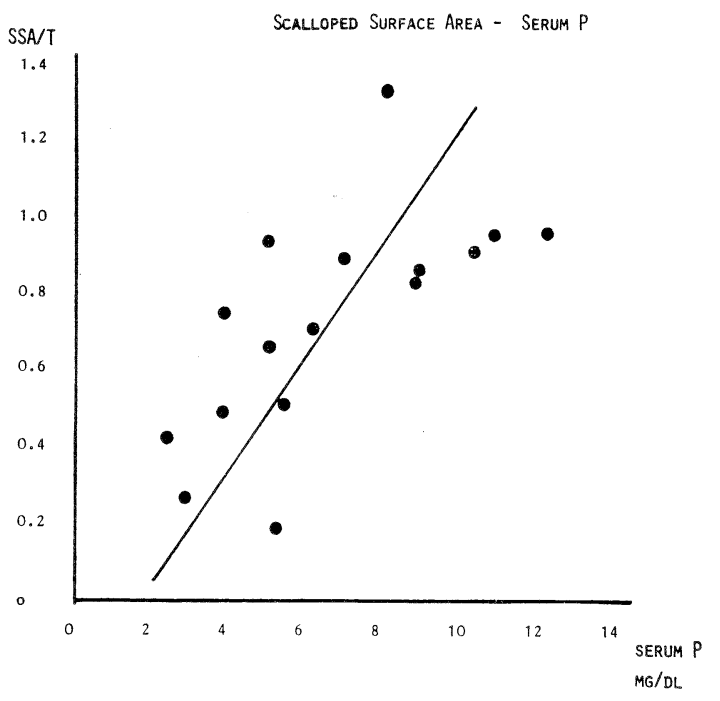

骨の稜を表わす bone area や骨稜の表面積はコントロ 一ルと有意の差は見られず（図 5), 類骨で覆われてい る骨稜の表面積や吸収面は, 図6のようにコントロール に比べ増加している.

また,PTHは 9 例が高值を示し, 最高值 $9.9 \mathrm{Ng} / \mathrm{ml}$ で 7 例は正常範囲内である. Ca, Pは図7のごとくである.

生化学的検查成績亡非脱灰標本の組織学的定量との相 関を検討すると，PTH は bone area（図 8 ）や骨稜表

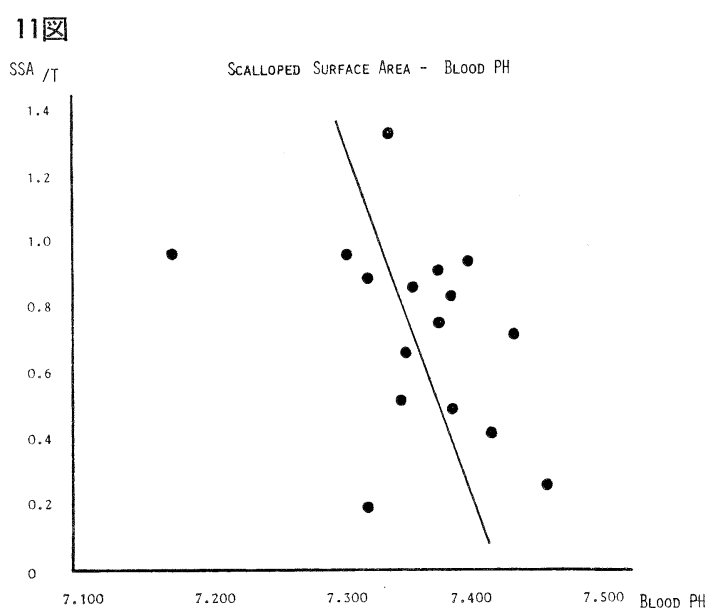

12図

OSA/T

Osteold Surface Area - S. AL-P

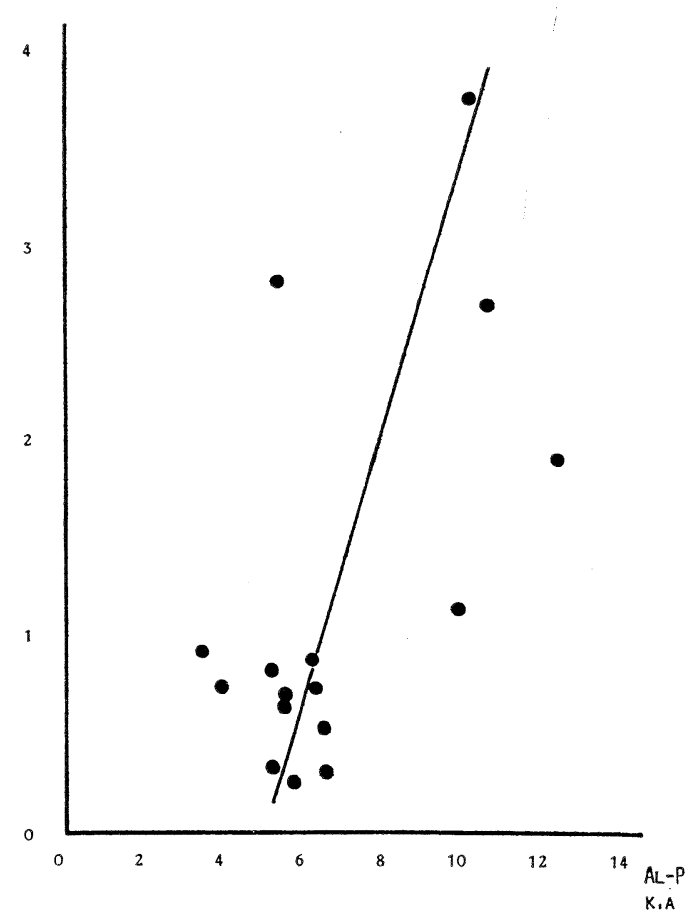


面積と有意の相関を示した（図9）。

$\mathrm{P}$ は，骨稜吸収面積と正の有意の相関を見（図10）, $\mathrm{PH}$ は骨稜吸収面積と負の相関があった（図11)。とのと とは，P及び PH が骨稜吸収面積との間に何らかの関係 があるととを示している。また，アルカリ・フォスファ ターゼも osteoid surface area と有意の相関を示して いた（図12).

レ線像では，16例中，頭蓋骨顆䊀状骨吸収陰影を示し たもの 8 例, 崡槽硬膜消失 4 例, 手指骨や足指骨の骨皮 犋に線状陰影を示したすの6 例で，骨膜下吸収像亡思わ れるあのは 1 例であった。

図13はさきに述べた症例の左中手骨であり，レ線像で 中手骨における変化が最すとらえやすく，他の部位での 所見の判谠は困難であった。そして，とのような軽微な レ線学的所見にあか加わらず，非脱灭標本での観察では 䫓著な那見を得ることがでさた。また，PTH と生化学 検㚗との間に有意の相関は見られなかった。
図13

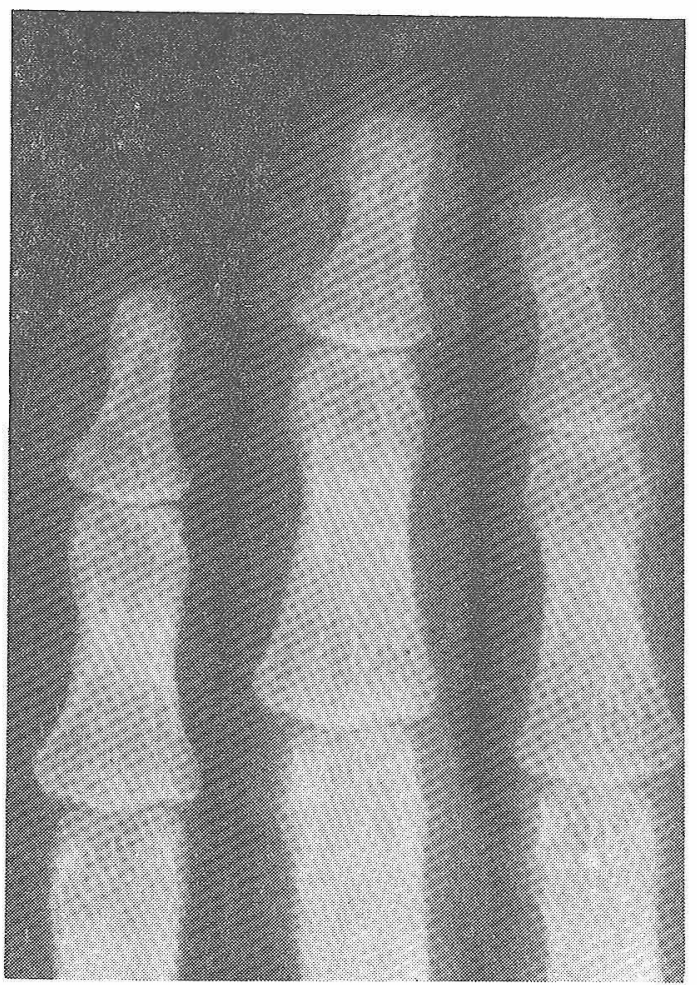




\section{誌上発表 27 (福光ら)}

最近私共は，血液透析をうけている末期腎不全患者に 病的骨折を契機として上皮小体腺腫を発見，摘除した。 この症例について，1, 手術の効果と術後の管理 2 , 診 断上の問題点 3 , 上皮小体亜全剔至行なわずに単発性腺 腫のみを行なったととが妥当であったか。などを検討し たい。

症例 60歳主婦 (図 1), 全経過, 約11年前より 足が弱り転び易くなった。乙の頃高熱之膿尿があり重篤 な腎孟腎炎と診断された。乙れに前後して激しい口渴， 多飲，多尿があった。 3 年前糖尿病の治療中に低血糖発 作で入院した際，慢性腎不全を指摘された。その 2 力月

図 1 症例 1 の経過表

60 才女性, 単発性腺腫 $(11.6 \mathrm{gm})$
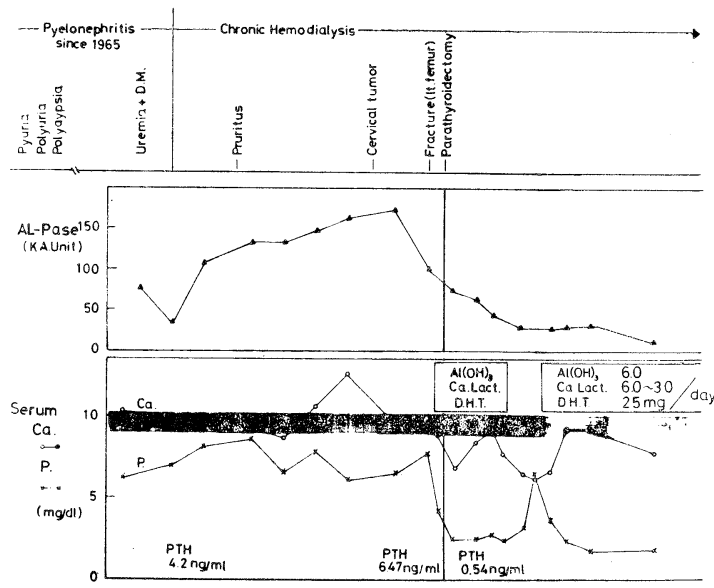

\begin{tabular}{c|c|c|c|c|c|}
\hline $1965-1971$ & $\begin{array}{c}\text { kut. Sept. Dec } \\
1972\end{array}$ & Mar Jun Sept. Dec & $\begin{array}{c}\text { Mar. Sun. Jut. Aug. Sept Oct. Nov. Dec. } \\
1973\end{array}$ & $\begin{array}{l}\text { Jan } \\
1974\end{array}$ \\
\hline
\end{tabular}

後から週 3 回の血液透析をうけるようになった． 1 年前 歩行中に左大腿骨頸部に病的骨折を抏てした。そそれまで に $1 \sim 2$ 度血清 $\mathrm{Ca}$ 值が僅かに正常值をこえていたこ と，Al-P が異常高值で骨型であったとと，頸部に腫瘤 がふれたととから手術を行なった. $11.6 \mathrm{~g}$ の単発性上皮 小体腺腫（主細胞）を摘除した。術後は $\mathrm{Ca}$ 剂，アルミ ゲル，ビタミンDを投与して，Ca 值をほぼ正常に $\mathrm{P}$ 值 を低值に保つことができた。術後10力月の現在，骨病 変, 動脈の石兏化は著明に改造して, 動脈は触猃であ軟 化した. Al-P 值は術後直線的に下降し，現在は正常上 限值を示している。[考察]血液透析治療が普及してか ら，2次性上皮小体機能㐫進症は顕著な形で現われるこ とが多くなっているままた腎移植によって腎機能を回復 した患者の中に，上皮小体機能元進症がそのまま進行す る例屯報告されている。 てれらの症例で外科的に摘除さ
れた上皮小体は hyperplasia から adenoma 更には carcinma にいたる様々な形態学的変化を呈している。原 発性上皮小体機能立進症に扔いても，その終末期には腎 不全を起とす例がほとんどであると考えられるから，末 期の慢性腎不全患者に見出された上皮小体異常について は， 2 次性， 3 次性，原発性の区別が必ずしも可能では い.乙のような知見は，上皮小体腫場の発生機序を考え る上に極めて興味深い問題を提起すると同時に，どのよ うな治療法をとるべきかという間題にも直接かかわって 来る. 本症例では, 腎不全の極度の悪化に伴なって骨の 脱灰や血管の石灰化が急涑に進行したことは疑い得ない 事実であるとしても，adenoma が先か，腎不全が先か という疑間については憶測の域を出まい。しかし全体的 な臨床症状の経過から見れば，原発性上皮小体機能六進 症が先にあったと考えるのが妥当である.

また, 最近経験した 27 歳女性の 4 腺の過形成（合計 $4.1 \mathrm{gm}$ ) を呈した症例を追加する(図 2).

結論 1 本症例のように血管の石灰化や骨病変を伴な った末期腎不全患者には，手術を要する上皮小体異常の 存在する可能性が少なからずある，2，その診断にあた っては血清 $\mathrm{Ca}$ 值よりも，骨レントゲン検査， $\mathrm{Al}-\mathrm{P}$ ア イソザイムの測定がより有力であった。 3 , 本症例で は，珼在までのところ単発性腺腫だけの摘除で十分な手 術効果があった。 4 , 術後の $\mathrm{Ca}$ 凨, アルミゲル，ビタ ミンDの投与は病変の改善に明らが寄与した。

図 2 追加症例の経過表 27 才女性， 4 腺過形成 $(4.1 \mathrm{gm})$

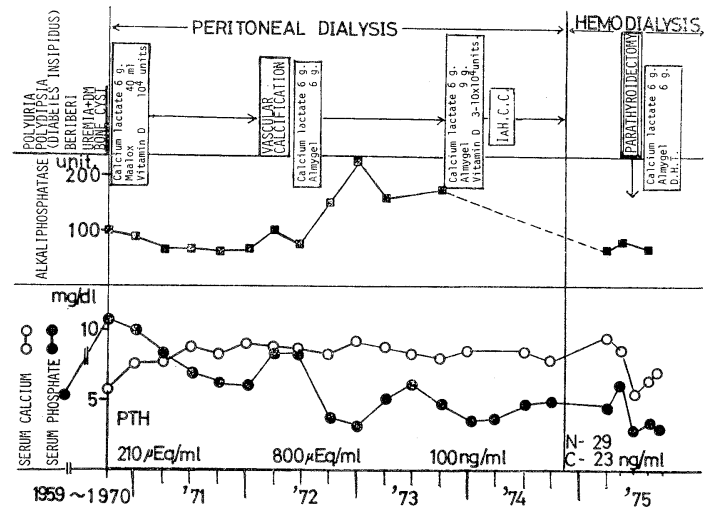

\section{誌上発表 28 (西島ら)}

長期透析患者に怙ける合併症として，カルシウム代謝 障害が最近注目されているが，我々禾間けつ的腹膜灌流 を施行し約 6 力月後に買所性石扊沈着症を来たした 1 例 を経験したので報告する。 
症例は31歳の女性で, 高血圧, 視力障害, 全身浮腫, 抢よび心不全症状が著明で救急入院した. 入院時の検查 所見は表 1 の如くである. 入院後, 各種降圧剂”利尿剂 の投与にも拘わらず，臨床症状の改善が見られないため に, 週 $2 \sim 3$ 回の間けつ的腹膜灌流を施行した. 透析療 法開始後は，順調な経過をとったが，透析開始後 6 力月 目頃より, 左の手関節, 右手の基節関節, 末節関節の腫 張と痛みを訴えるようになり,さらに2 力月後には左の 足関節にも関節炎様所見を認めた。レ線的には, 右手の 第 2 指之第 3 指の基節関節部の石灰化陰影々, 左手関節 部の腫瘤に一致した石灰沈着を認めた。

一般に腎不全患者に㧍けるカルシウム代謝障害は，力 ルシウム・燐積が70以上になると起とりやすいと言われ ている.

骨の脱灰を抑えるためには，消化管からのカルシウム 吸収を促進させるか，透析液のカルシウム濃度を上げれ ばよいとされているが, 後者の場合, 吸収量は増加する が透析によるP Hの上昇に伴って異所性石灰化を沶てし やすくなるので, 血清燐値をアルミゲルなどの投与で充
表 1 入院時検査所見

血圧 : $222 / 140 \mathrm{mmHg}$ 血液所見 : 赤血球数 $221 \times 10^{4}$ 血色素 $6.98 \mathrm{~g} / \mathrm{dl}$, ヘマトクリット $20.9 \%$, 白血球数 4300 血液化学所見: 総蛋白 $4.5 \mathrm{~g} / \mathrm{dl}, \mathrm{BUN} 99 \mathrm{mg} / \mathrm{dl}$, クレアチニン $12.9 \mathrm{mg} / \mathrm{dl}$, 尿酸 $410.0 \mathrm{mg} / \mathrm{dl}, \mathrm{Na} 140$ $\mathrm{mEq} / 1, \mathrm{~K} 6.5 \mathrm{mEq} / \mathrm{l}, \mathrm{Cl} 111 \mathrm{mEq} / 1, \mathrm{Ca} 4.0 \mathrm{mEq} / \mathrm{l}$ P7. $9 \mathrm{mg} / \mathrm{dl}$, 眼底所見 : Keith-Wagener 分類の II 群. 心胸比 : $59 \%$

分下げておくことが必要である。

当症例の腹膜透析に使用した灌流液のカルシウム濃度 はで， $4.5 \mathrm{mEq} / 1$ 血液透析に用いられる一般の透析液の $2.5 \mathrm{mEq} / 1$ に比べるとなかり高くなっている，透析液の 至適カルシウム濃度については異論のある所であるが, 単にカシウム濃度を高くするだけで良いという考えには 問題があると思わ机る。な技当症例は，アルミゲル $3 \mathrm{~g} /$ day の服用により約 3 週間後には自覚症状は消失し, 約 2 力月後には他覚的所見の改善を見ている. 


\section{討 論}

千野 どうあありがとうございました。これから討論 に移るわけですが，演者の方，どうぞ壇上に招上がりに なってください。

平沢 その間を扔借りしまして，今まで演者が発表さ れたととを若干臨床的な立場でまとめてみたいと思いま す.

長期透析に伴って一一てれはやり方はいろいろあると 思いますが，現在一般にやられている方法という意味で でざいますその経過に伴いまして，腎病変はどうも確実 に進行するようである。そして，骨病変の内容は，線維 性骨炎, 骨粗鬆症, それから骨軟化のいずれも見られ， かつ混在している. 生化学的に見れば脱灰す認められ る。診断面では，X線所見，あるいは一部の生化学的所 見之骨生検像は必ずしも一致しない。骨塩量はフォート ン・アブソープション・テクニックの測定はかなり信頼 性が持てるのではないか。れから，活性型ビタミンD は, 線維性骨炎や骨軟化の改善に，あるいは骨塩量の増 加などをむたらす，それから，著しくかつ克服できない ような副甲状腺機能立進症を見る場合は，亜全摘が必要 なのではないかというようなととであったと思います。

とてろで, 誌上発表に今までと少し違う演題が提出さ れておりますので，まずその要点をお知らせいただきた い之思います。それから共通的な問題で若于の討論をや ってみたいというように考えて打ります. 福光先生打願 いいたします。

小原 共同研究者の小原です．私ぞも透析患者に上皮 小体の異常を見出した症例を経験しましたので，追加さ せていただきます。

私どもは 2 例, 上皮小体腺腫之 hyperplasia 各 1 例 ずつを経験しております. 1 例は63歳の女性で, 約 2 年 間，DMという診断で血液透析をして抒ります間に，非 常に高いアルカリ・フォスファターゼ值に気付いており ましたけれども, 2 年後に大腿骨の骨折を起としまして， そのときに頸部に大きな骨頭大の腫瘤を触れまして，一 応ハイパーパラサイロイディズムだろうというととで手 術しました. この症例は, 組織学的にはチーフセルの adenoma というふうに考えられまして，原病としてて secondary れをと言っていいか, primary と言うべきか ということで私ども悩んで扮りますけれども，一応 pri一 mary の adenoma であったととが原発なんじゃない か。腎不全で血液透析についた患者の中には，てういう ふうな上皮小体腺腫が初めに原疾患としてあって，それ が見過ごされているケースがありはしないか，そういう
ことを経験しました.

屯う 1 例は, 約 5 年間の血液透析と腹膜灌流を経過し た27歳の女性の症例でありまして，乙の症例は小学校 6 年のときから腎不全が見出されておりますけれど屯，尿 毒症に陥りました 5 年前に既に cystic な変化が骨にあ りまして，それが腹膜透析の経過中進行性に増悪しま して，一応八イパーパラサイロイディズムとして手術を 行ないましたけれどあ，乙の症例であアルカリ・フォス フアターゼは異常に高く，4つと屯上皮小体は hyperplasia を示して扔りまして，乙の症例む本当に primary と言っていいのか，と言っていいのか，ちょっと悩んで いる症例です.

平沢 secondary か Primary かという問題はしば しばあるのではないかと思いますが，また後で時間があ りましたら演者の方々の御意見もお聞きしたいと思いま す.

続いて，西島先生いらっしいのましたら抢願いいたし ます。

\section{西島 大阪市立大学浨尿器科の西島です。}

われわれも間歇的腹膜灌流を行なっておりまして, 約 6 力月後に異所性石灰沈着症を来しましたた 1 例を最近 経験いたしております。

透析開始後, 順調に経過しておりましたけれどあ, 約 6 力月目ごろから, 先ほどから写真を見せていただいて おるのと同じようなレ線像と，指節関節，末節関節の腫 脹, 痛みを認めるようになりまして, 一応異所性石灰沈 着症と診断いたしました。乙の症例は腹膜灌流なんです けれどあ，われわれのところで行なっております血液透 析の患者さんの場合には，1例むとういった骨変化を認 めて㧍りません，血液透析に使用しております $\mathrm{Ca}$ 濃度 は，われわれのととろでは $2.5 \mathrm{mEq} / 1$ で，乙の症例に 用いました腹膜灌流の透析液は $4.5 \mathrm{mEq} / 1$ です。先ほど 岡沢先生からむ $\mathrm{Ca}$ 濃度は $3.5 \mathrm{mEq} / 1$ が至適じゃない かというお話がございましたけれどす，そういうことに 関しまして，一応 $\mathrm{Ca}$ 濃度はごれぐらいが至適かという ことを教えていただきたいと思ってての演題を追加させ ていただきました。

平沢 たまたま西島先生の方から $\mathrm{Ca}$ 濃度の適当なも のはどれぐらいかという御質問がでざいました．先ほど からの話でも，Ca 濃度の上手な使い方によって骨病変 の抑制ができないか，進行の抑制ができないかあるいは PTH の分泌抑制ができないかというようなととは，皆 様みな技考价なっているととではないかと思いますの で，その辺から演者の及方の御意見を㐨聞きしていって みたらと思います。 
まず鈴木先生，適当な $\mathrm{Ca}$ 濃度として，てれは血液透 析に限っても，腹膜灌流に限ってもよろしゅうございま すが，意見を扮願いしたいと思います．

鈴木 ただいまの異所性石灰化の問題では, 特に実際 的に経験することは，腹膜灌流で治療をやっている方が 異所性石厕化を見る例が多いということは，臨床的に経 験するととだと思います。

それから，ただいまの透析液の Ca 濃度はオプティマ ムどの程度がいいのかというととになりますと, 一つに は透析の頻度, それから 1 回透析の量, 結局, 週どの程 度の透析をやるかということになると思いますけれど

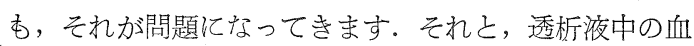
液の酸性をアルカリ性に戻すために，普通は酢酸を使っ ているわけですが，そういうすのの量が問題になってく る。それから，特に骨変化よりも異所性石灰化の点を問 題にしますと，血清Pのコントロールというととが非常 に大きな問題になってきますので，そういうととを抜き にしては透析液の $\mathrm{Ca}$ 濃度云々はちょっ之語れないので はないかと思います。

仮に，私どもがいまやって扔りますととから結論的に 中し上げれば，酰酸濃度は大体 $37 \mathrm{mEq}$, 血清 $\mathrm{P}$ は極力 $6 \mathrm{mg}$ 以下にアルミゲル等の投与でもって下げる，そうい う条件の下で透析液の Ca 濃度はどうだというととにな りますと，現在では $7.5 \mathrm{mg} / \mathrm{dl}, \mathrm{mEq}$ に直しますとその 半分ということになりますけれどす，その程度で，しか あ週 3 回が今のとてろよろしいのではないか. ただ，先 ほどあ沶示ししましたように，そういうととをやってお りましても骨の脱灰は進みますし, 骨生検あるいは剖検 例の骨を見ましても，二次性副甲状腺機能六進症を見ま してあ75\%組織学的に見られる。あるいは骨軟化症す 40 \%ぐらい見られるというようなととですから，私ど屯が 今やっている週 3 回でしか屯 $7.5 \mathrm{mg}$ の $\mathrm{Ca}$ を使って む, 決しててれは絶対的にいいものだとは言えないと思 います。

平沢 山本先生, いかがでしょうか.

山本 今まで何回加いいろな会に Ca 濃度の適正を 言われておりますけれどあ，今鈴木先生が言われたと同 じように，Ca だけで云々するよりあ，やはり血清 Pの コントロール之か, 透析の時間, わずか 1 週間に 20 数時 間程度の透析だけで血中の Ca 濃度をコントロールでき るものじゃないものですから，そういうほかの意味から あ考えなければならないと思い，私たちがやっているの は, 市販 AKソリ夕に水道水で希勫して $7 \mathrm{mg}$ 弱, その 程度で十分じゃないかと思います。

平沢 大方の意見は招 2 人の御意見とかなり一致する
のではないかと思います。いろいろなファクターが関係 すると思いますが，少なくとも透析中には Ca が体にと ってポジティブな状態でいかなければならないだろう， しかし，異所性石灰化を促進するような著しい流れ込み は問題があろう，というようなととではないかと思いま す.

その次に，時間がごくかずかしか残されておりません ので，はなはだ恐縮ででざいますが，私，臨床的な立場 で，少し代表して質問させていただくととを扮許しいた だきたいと思います。

骨病変が，たとえげX線所見とかなんかとあまり一致 しないということになったら，われわ臨床家として は, 何を基準に骨の変化が起こっているか, 強いか弱い かというようなととを知ったらいいか，そしてそういう あのは定期的にはどのくらいの頻度で見ていったらいい かというととを, 整形の先生が御出席ででざいますの で，ちょっと怙聞きしてみたいと思うのであります。こ の腎性骨症というのは, どこの骨をレントゲン的な観察 をしたらいいのか，時間的にはどれくらいの間隔でいっ たらいいのか，少し教えていただきたいと思います。若 菜先生, いかがででざいましょうか.

若菜 ただいます述べさせていただいたように，私ど あはレントゲンを 122 名を先ほど述べましたようにやっ てみまして、コントロール群と比較したわけなんですけ れども，それと同時に，併行的にそういうととの一応裏 付けに各々患者さんの骨生検ができますと非常にいいわ けなんですけれどあ，そのとてろができませんし，そう いうふうなデータ，あるいは今までやられたような Nordin とか Meema とか Singh とか，そういったの を参考にしてやって扔ります. それ以上はちょっと無理 ではないか。ただ，最近ミネラルアナライザーというよ うな，先ほど東京女子医大の先生が拈っしゃったような あの機械とはちょっと違うのですけれど屯, 私らむその 機械で今フォローをやっております.

平沢 鳥越先生, 御意見を敄聞かせいただきたいと思 います。

鳥越 実はこういうリサーチを始めたばかりで，はっ きりしたことはまだ丮し上げられないのですけれども， レントゲン写真ではまだ軽微なうちに組織学的にはかな り出てきているというととで，レントゲン写真は，今ま で50数例見た感じだけで言いますと，指の骨に比較的見 やすい，そして，透析してどのくらいたったらどのくら い変化するかというととは，まだてれからの研究にまっ て，ててではっきり申し上げることは私はできないので すけれどす。 
平沢これからの問題む多いのではないかと思います ので，関係者皆様の御検索を打願いいたします。

それから, ビタミンDの効果というのが, 特汇活性型 の問題がこれから大きくなってくると思いますが，フォ ートン・アブソープション・テクニックを用いた活性型 ビタミンDの効果というようなととで岡沢先生打話にな りましたが，乙れは骨病変ではじんな骨病変が改善され るというように技考えでしょうか。

岡沢 ビタミンDをやり出したのが去年の中でろから なわけですけれども，それを再検討した1つの動機にな ったのが，先ほど表に示したような，無腎で 2 年間あの ように血清 $\mathrm{Ca}$ 值, $\mathrm{P}$ ，アルカリ・フォスファターゼ が，血清 $\mathrm{Ca}$ 值であればそれほど下がらない，アルホス であれば12単位まででそれ以上いかないということから でありまして，それ之，DHT を6例使っていたわけ ですけれどあ，DHT によって骨塩量は上がるけれどあ くる病性変化は一向によくならないという2つのととか ら, 従来, 1-25- $\mathrm{OHD}_{3}$ でないとだめだという動物実験 などから，私たちむ結局ビタミンをやってもだめなんじ やないかというふうに思っていたわけですけれどす，ぞ うも先ほどの $2 つ$ つ功, ビタミンDをむう一度や ろうということになりまして，とり始めたわけです，そ の結果, 表にも示しましたけれども, 特咀病変が多彩 であるのは小児例なむのですから，小児 6 例のうち 5 例 に使ったわけですけれどあ，骨塩量の面ではあのように 増加しているという結果が出ています。また，成人例で あ出ています。

ぞういう骨病変に対していいかというととですけれど も，一応病変としてはくる病作用ということですので， くる病性変化のあるあのに特に使っていますけれどあ特 にバイオプシーをして, それに対して一つ一つ適応を決 めていけば一番いいのかむしれませんけれも゙あ, バイオ プシーをするということになりますと, 非常に患者さん のととを思いますと忍びないので, レントゲン写真, あ るいは臨床経過, 血清生化学的なデータから判断して使
って扔ります。

平沢 ビタミンDの効果を骨生検上で御覽になった方 はいらっしゃいませんでしょうか.

鈴木 先ほど図で㧍示ししなかったのですが，という のは, シリーズでバイオプシーをやった症例ででざいま せんでしたので怙示ししなかったのですが，透析開始前 加ら既飞著明な骨軟化吸収像, それからルーサースゾー ンということで, 二次性副甲状腺機能充進症が確実にあ ったというととと，骨軟化症も確実にあったと思われる 50歳の女の方に透析を始めましたとてろ, 急速に了ルカ リ・フォスファターゼが上昇してまいりまして, 60 単位を 超えるようなアルカリ・フォスファターゼが出てまいり 宗したので, その時点で dehydrotachysterol を使いま したところ，4カ月から5 月月使いましたところでアル カリ・フォスファターゼが急速に正常值に復しまして, そ の時点でテトラサイクリンをラベルしてバイオプシーを やりましたところで整形の先生の和返事を頂きましたと ころでは，その時点では既に骨軟化吸収像は消失してい るわけででざいます。そういうことで, 臨床的には明ら 加に次性副甲状腺機能進症は治療している, ないし はかなり改善したということは確実なわけででざいます が，そういう点で見ますと，テトラサイクリンが二重標 識でありまして確実に識別できる。ちなみに，コントロ ールとしまして，ビタミンDを投与しなか力た人のテト ラサイクリン・ラベルを見ますと， 2 回標識をしまして あ全然識別ができないというととででざいますから，や っぱり活性型ビタミンDではなくても dehydrotachysterol を使えば，少なくとも骨軟化症の石灰化を促進す ることは可能だと思います.

平沢 まだ PTH と骨病変との関係とか，臨床的な PTH の評価とか, いろいろな問題が残されているので ありますが，予定の時間が来てしまいましたので，ての 辺でてのセクションを終わりたいと思います.

多くの症例をまとめてお示しいただきまして, 演者の 方々，大変ありがとうございました。 